\title{
Epigallocatechin Gallate for Management of Heavy Metal-Induced Oxidative Stress: Mechanisms of Action, Efficacy, and Concerns
}

\author{
Iwona Zwolak (D)
}

check for updates

Citation: Zwolak, I. Epigallocatechin Gallate for Management of Heavy Metal-Induced Oxidative Stress: Mechanisms of Action, Efficacy, and Concerns. Int. J. Mol. Sci. 2021, 22, 4027. https://doi.org/10.3390/ ijms22084027

Academic Editor: Seung-Hong Lee

Received: 22 March 2021

Accepted: 12 April 2021

Published: 14 April 2021

Publisher's Note: MDPI stays neutral with regard to jurisdictional claims in published maps and institutional affiliations.

Copyright: (c) 2021 by the author Licensee MDPI, Basel, Switzerland. This article is an open access article distributed under the terms and conditions of the Creative Commons Attribution (CC BY) license (https:// creativecommons.org/licenses/by/ $4.0 /)$.
Centre for Interdisciplinary Research, Laboratory of Oxidative Stress, The John Paul II Catholic University of Lublin, Konstantynów Ave. 1J, 20-708 Lublin, Poland; iwona.zwolak@kul.pl

\begin{abstract}
In this review, we highlight the effects of epigallocatechin gallate (EGCG) against toxicities induced by heavy metals (HMs). This most active green tea polyphenol was demonstrated to reduce $\mathrm{HM}$ toxicity in such cells and tissues as testis, liver, kidney, and neural cells. Several protective mechanisms that seem to play a pivotal role in EGCG-induced effects, including reactive oxygen species scavenging, HM chelation, activation of nuclear factor erythroid 2-related factor 2 (Nrf2), anti-inflammatory effects, and protection of mitochondria, are described. However, some studies, especially in vitro experiments, reported potentiation of harmful HM actions in the presence of EGCG. The adverse impact of EGCG on HM toxicity may be explained by such events as autooxidation of EGCG, EGCG-mediated iron $\left(\mathrm{Fe}^{3+}\right)$ reduction, depletion of intracellular glutathione (GSH) levels, and disruption of mitochondrial functions. Furthermore, challenges hampering the potential EGCG application related to its low bioavailability and proper dosing are also discussed. Overall, in this review, we point out insights into mechanisms that might account for both the beneficial and adverse effects of EGCG in HM poisoning, which may have a bearing on the design of new therapeutics for $\mathrm{HM}$ intoxication therapy.
\end{abstract}

Keywords: epigallocatechin gallate; EGCG; antioxidant; heavy metals; reactive oxygen species; oxidative stress

\section{Background}

Heavy metal (HM) pollution is one of the major public health concerns in Europe and beyond. Features of heavy metals that make them particularly dangerous for humans include their high toxicity potential, the ability to bioaccumulate in plants, and the biological buildup in the food chain [1,2]. In addition, HMs as pollutants are not degradable and can persist in the environment for a long time, thereby posing a significant threat to human health [1]. For example, a high concentration of arsenic (As) is still being reported in the topsoil of the historical mining areas in Southern Saxony (Germany) [3], and a high mercury $(\mathrm{Hg})$ concentration has been found in the soils of the former mining Middle Spiš area in Slovakia [4]. Sodango et al. [5] reported that as much as $10.18 \%$ of farmland soils, which support $13.86 \%$ of grain production in China, are affected by HM pollution originating mainly from anthropogenic activities. Other data report that HM contamination may significantly contribute to the cancer epidemic in sub-Saharan Africa [6]. Clearly, people working in an industry that uses HMs such as mining industry [7], automotive parts industry [8], nonferrous metal industry [9], or tile industry [10] are at higher risk of exposure to HMs. However, others may also be threatened by potential HM exposure, for example through living in HM-polluted industrial areas [11] or prolonged ingestion of HM-contaminated cereals or fish [12] (more examples of non-occupational sources of HM exposure are shown in Table 1). The continuing danger from HM exposure is supported by the fact that as many as four HMs ( $\mathrm{As}, \mathrm{Pb}, \mathrm{Hg}$, and $\mathrm{Cd}$ ) have been included in the top 10 in the Agency for Toxic Substances and Disease Registry (ATSDR) priority list of hazardous 
substances [13]. This list identifies substances that ATSDR and the Environmental Protection Agency (EPA) consider as "the most significant potential threat to human health due to their known or suspected toxicity and potential for human exposure" at Superfund sites in the U.S. [13]. In addition, four HMs (i.e., $\mathrm{As}, \mathrm{Cd}, \mathrm{Cr}(\mathrm{VI})$, and $\mathrm{Ni}$ ) have been classified as class 1 carcinogens by the International Agency for Research on Cancer [14], which implies that they are known to cause cancer in humans. Furthermore, HM toxicity has been linked with neurological disorders, kidney dysfunction, allergy, and male and female infertility $[15,16]$.

Table 1. Potential non-occupational exposures to heavy metals (HMs).

\begin{tabular}{|c|c|c|c|}
\hline HMs & Exposure Source & Adverse Effects on Human Health & Ref. \\
\hline $\mathrm{Ni}, \mathrm{V}$ & $\begin{array}{l}\text { Fine particulate matter in the urban } \\
\text { environment }\end{array}$ & $\begin{array}{c}\text { Possible contribution to respiratory symptoms in children (in New } \\
\text { York City) }\end{array}$ & [17] \\
\hline $\mathrm{Cd}$ & Cigarette smoke & Increased risk of cardiovascular diseases (in Sweden) & [18] \\
\hline $\mathrm{Cd}$ & Rice & Increased risk of kidney diseases (in Japan) & [19] \\
\hline $\mathrm{Cd}, \mathrm{Al}$ & Shellfish & Allergic eczema & [20] \\
\hline As & Fish & Possible contribution to nonmelanoma skin cancer (in Singapore) & [21] \\
\hline As & Highland barley & Increased probability of cancer risk (in western Tibet) & {$[22]$} \\
\hline $\mathrm{Ti}$ & $\begin{array}{l}\text { Titanium-based dental and orthopedic } \\
\text { implants }\end{array}$ & Allergic eczema & [23] \\
\hline $\mathrm{V}$ & Titanium-based orthopedic implants & Systemic dermatitis & [24] \\
\hline $\mathrm{Pb}$ & Ayurvedic medicines & Abdominal pain & [25] \\
\hline $\mathrm{Pb}$ & Coffee & Possible contribution to disease burden in heavy coffee drinkers & [26] \\
\hline $\mathrm{Al}$ & Cosmetics (antiperspirants) & Possible contribution to breast cancer & [27] \\
\hline
\end{tabular}

Chelation therapy is the major pharmacological method used for the treatment of toxic metal poisoning [28]. In this therapy, a chelating agent combines with metal ions forming a stable ring-like structure called a chelate. The chelate structure is more watersoluble than the toxic metal, which facilitates removal of the toxic metal from tissues and excretion thereof by kidneys $[29,30]$. However, there are drawbacks associated with chelation therapy, mainly with regard to the potentially adverse health effects of chelators, such as gastrointestinal symptoms, nephrotoxicity, and neurological effects [28]. There are also other concerns. For example, dimercaprol (BAL) is often dissolved in peanut oil, which may induce allergic reaction in people susceptible to peanuts. Moreover, this chelating agent has a narrow therapeutic window and is administered through deep intramuscular painful injections [28,31]. BAL and $\mathrm{CaNa}_{2}$ EDTA (calcium disodium ethylenediamine tetraacetic acid) were reported to redistribute $\mathrm{As}$ and $\mathrm{Pb}$, respectively, from other tissues to the brain, and DMSA (meso-2,3-dimercaptosuccinic acid) was shown to increase $\mathrm{Hg}$ levels in motor axons [29]. In addition, the efficiency of chelating agents is not always satisfactory. For example, as reported by Li et al. [32], treatment of As poisoning with chelating agents brings positive short-term effects, whereas the long-term effects of treatment with chelators are below expectations. Currently, no effective chelating agents can be recommended for the treatment of $\mathrm{Cd}$ or $\mathrm{Cr}$ toxicity in humans [28]. Lastly, the high cost of chelation treatment hinders its use in developing countries such as sub-Saharan countries where HM pollution is regarded as a significant health risk to the population [6,15]. Therefore, there is a need for development of potential alternative methods with antidotes that will help to increase the efficiency of chelators or allow substituting these compounds.

Although the efficacy of chelation therapy in the treatment of HM toxicity is undebatable, new approaches are being developed to enhance clinical treatment of HM toxicity and reduce potential adverse effects that may arise from the chelation treatment. One of such approaches includes combining chelation therapy with administration of antioxidants or the use of antioxidants alone. Such combination therapy (chelator and antioxidant) has been suggested to increase toxic metal mobilization and excretion and reduce oxidative stress markers [29,31]. Different natural antioxidant-rich food products have been proposed to be included in a daily diet as a safe and cheap way of blocking the adverse effects of HMs on the human body $[20,33,34]$. They include edible plants like garlic (Alium sativum), onion, 
broccoli, coriander, Ginkgo biloba, and green tea (Camellia sinensis) [15,20,35]. Among them, green tea receives significant attention in this regard. Green tea has been reported to prevent As-induced neurotoxicity in rats [36], reduce the bioaccessibility of dietary mercury [37], and protect against $\mathrm{Cd}$-induced damage to rat testes [38]. Green tea solutions have been found to prevent $\mathrm{Pb}$ and $\mathrm{Cd}$ toxicity in animals through enhancement of endogenous antioxidant mechanisms and chelation of these metals (reviewed by Winiarska-Mieczan [33]). The polyphenol epigallocatechin gallate (EGCG), belonging to the chemical class of flavan-3-ols (or catechins), stands out as the most active and well-studied antioxidant in green tea.

EGCG (Figure 1) is the main green tea catechin accounting for $50-80 \%$ of the total catechin content [39]. EGCG is characterized by its antioxidant capacity through scavenging free radicals species or chelating metal ions [40]. Some studies show that EGCG is the most powerful catechin in scavenging intracellular ROS [41,42] and a more efficient ROS scavenger than vitamin C [43]. EGCG has also been demonstrated to have anti-inflammatory and anticancer properties $[44,45]$. There is a wealth of literature describing the beneficial effects of EGCG on various disorders, e.g., metabolic syndrome [40], kidney diseases [46], neurological diseases [47], and cancer [48]. The suggested beneficial properties of EGCG, including the antioxidant, anti-inflammatory, and anticancer effects, are very desirable features for its application in the prevention of HM toxicity. Therefore, unsurprisingly, many researchers have challenged this compound in the therapy of HM poisoning.

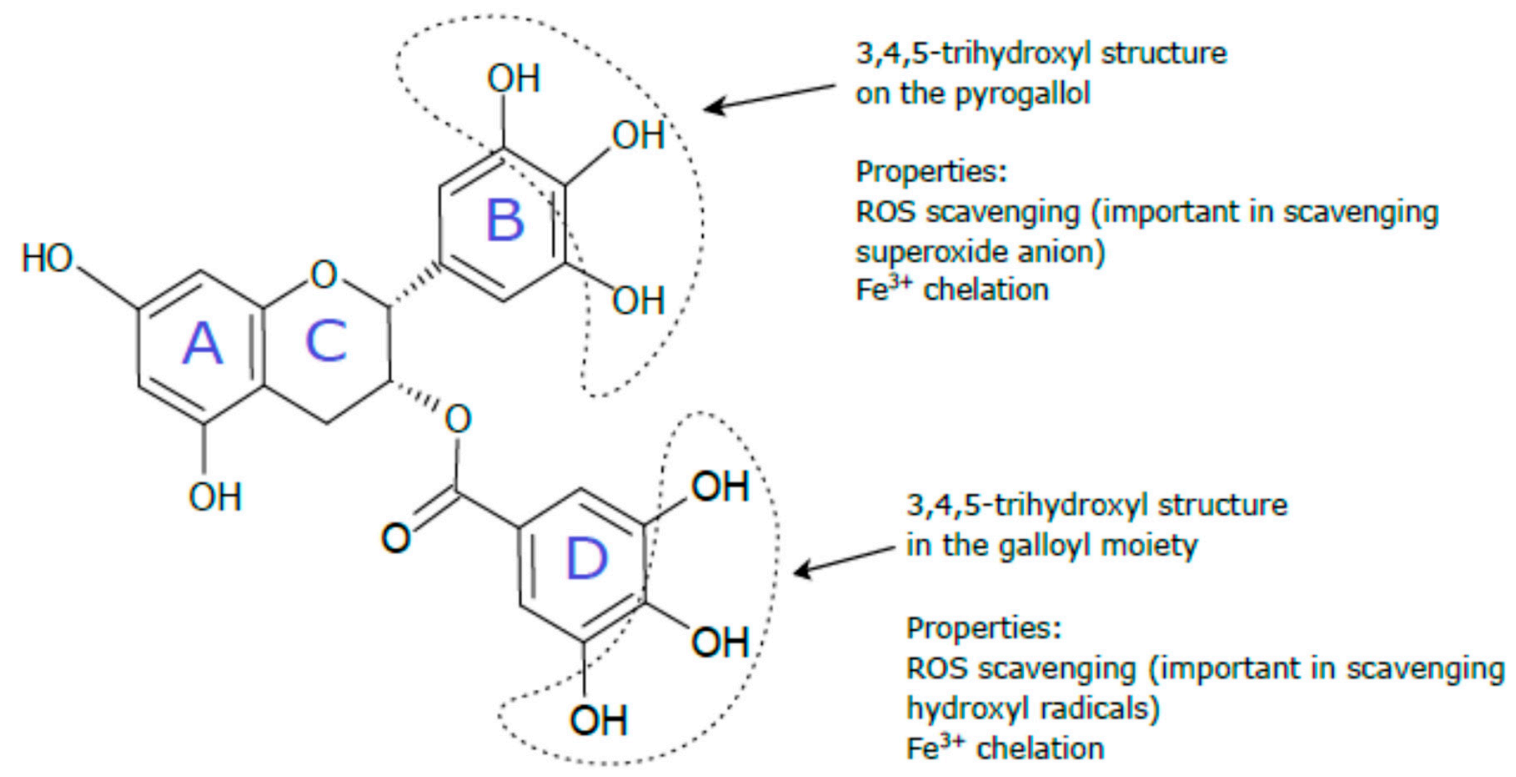

Figure 1. Epigallocatechin gallate (EGCG) structure. EGCG is composed of four rings designated as A, B, C, and D. The A and $C$ rings form a benzopyran ring system, which is connected with the pyrogallol (the $B$ ring) and gallate (the $D$ ring) moiety at the C-2 and C-3 positions, respectively [45]. The role of the functional groups in the antioxidant properties of EGCG was described on the basis of other studies [49-51].

The EGCG-based treatment against HMs has been studied for more than a decade, but no comprehensive review and no extensive analysis have been conducted so far. To this end, we collected all studies published up to 2021 examining the effectiveness of EGCG treatment in HM intoxication in animal and cell culture models. In this review, we concentrate on studies that used pure EGCG (studies with GT extracts or GT infusions were excluded) to put the EGCG-specific actions in the center of attention. First, we shortly describe the current health risks related to each of the HMs (i.e., lead, arsenic, cadmium, chromium (VI), nickel, and mercury) in order to give a more updated picture of these metals to the reader. Secondly, based on the collected studies, we delineate EGCGinduced protective mechanisms against these HMs involving free radical scavenging, direct interaction of EGCG with HMs and enhancement of their excretion, enhancement 
of antioxidant defenses, and anti-inflammatory effects. In addition, since mitochondrial ROS generation is an important step in HM-induced cell damage [52], we also discuss the possible role of these organelles in the beneficial effects of EGCG. Moreover, we pay attention to studies describing increased HM toxicity in the presence of this catechin and the mechanisms through which EGCG may be involved in this effect. Finally, two issues are identified as potential obstacles challenging researchers. These are the low EGCG bioavailability and the safe EGCG dosing to achieve optimal responses without inducing adverse effects. We describe these problems to give a more complete picture of the EGCG potential in the therapy of HM-induced disorders.

\section{Heavy Metals As Toxicants: Health Risks and Sources for Exposure}

In this review, we focused on six $\mathrm{HMs}$ i.e., $\mathrm{As}, \mathrm{Cd}, \mathrm{Pb}, \mathrm{Hg}, \mathrm{Cr}(\mathrm{VI})$, and $\mathrm{Ni}$. We chose these metals taking into consideration the data of ATSDR and EPA, which regard four of these elements ( $\mathrm{As}, \mathrm{Cd}, \mathrm{Pb}$, and $\mathrm{Hg}$ ) as highly threatening to human health [13], as already mentioned in the background, and the data of IARC, which classify $\mathrm{Cd}, \mathrm{As}, \mathrm{Ni}$, and $\mathrm{Cr}(\mathrm{VI})$ as humans carcinogens [14].

\subsection{Lead}

People can be exposed to lead $(\mathrm{Pb})$ through inhalation of lead-containing particles emitted during metallurgical smelting or stripping leaded paint and through ingestion of $\mathrm{Pb}$-contaminated dust, water (from leaded pipes), and food (from Pb-contaminated containers). The other sources of toxic $\mathrm{Pb}$ exposure include unregulated cosmetics and medicines [53]. After absorption, $\mathrm{Pb}$ is distributed to mineralized tissues and soft tissues (liver, kidney, lungs, brain, spleen, muscles, and heart). Most $\mathrm{Pb}$ is accumulated in bones and teeth from where it can be mobilized in certain conditions such as lactation, pregnancy, broken bones, and kidney diseases thus elevating blood lead levels even after ceased $\mathrm{Pb}$ exposure [54]. Lead can induce harmful effects on the central nervous system (CNS) and kidneys as well as the immune, reproductive, and cardiovascular systems [15]. Children, infants in neonatal periods, and the fetus are particularly sensitive to $\mathrm{Pb}$ toxicity [55]. The high sensitivity of children to $\mathrm{Pb}$ results from the fact that they can absorb significantly higher amounts of $\mathrm{Pb}$ from a given source than adults e.g., children can absorb 50\% of $\mathrm{Pb}$ ingested after a meal, whereas adults absorb 20\% [54]. Additionally, children retain more $\mathrm{Pb}$ in the body and store more $\mathrm{Pb}$ in the brain [56]. The target system of $\mathrm{Pb}$ toxicity in children is the developing nervous system, which in turn exerts adverse effects on specific functional domains such as memory, language functions, and attention and executive functioning [56]. For example, it was estimated that as many as $0.5 \mathrm{mln}$ children under 6 years in the USA had blood $\mathrm{Pb}$ levels $\geq 5 \mu \mathrm{g} / \mathrm{dL}$ [57]. Noteworthy, blood $\mathrm{Pb}$ concentrations even below $5 \mu \mathrm{g} / \mathrm{dL}(50 \mu \mathrm{g} / \mathrm{L})$ are associated with subtle effects on the intelligence quotient (IQ) in children, and these effects worsen with higher blood lead levels [58]. Currently, the highest risk of $\mathrm{Pb}$ poisoning in children is noted in developing countries. As described by Amadi et al. [15], in recent years, many cases of $\mathrm{Pb}$ poisoning including deaths have been reported in Nigerian children with sources of exposure from mining, ore processing, agriculture, or use of $\mathrm{Pb}$-containing cosmetic and medicines. In high-income countries such as the USA, the main source of $\mathrm{Pb}$ poisoning in children is via the exposure to $\mathrm{Pb}$-contaminated dust and chips from deteriorating $\mathrm{Pb}$ indoor paints [59].

\subsection{Arsenic}

Arsenic (As) is a carcinogenic element contaminating groundwater in many parts of the world, especially in South Asian countries. Bangladesh, Pakistan, China, India, Nepal, and Cambodia are substantially affected by As groundwater pollution with As levels often much greater than the WHO arsenic limit of $10 \mu \mathrm{g} / \mathrm{L}$. The main source of As groundwater pollution in these areas is considered to be in their geology [60]. In addition, the use of arsenical pesticides, inappropriate disposal of arsenical chemicals [61], and burning of high-As coal may also release considerable amounts of As to the environment [32]. In 
addition to water, rice is the major plant-derived food that significantly contributes to human exposure to As [62]. The most characteristic symptoms of chronic As intoxication are dermal lesions, i.e., pigmentation of the body and keratosis of the palms and soles. Other clinical manifestations include weakness, anemia, neuropathy, liver enlargement, lung disease, and peripheral arterial disease [30]. According to IARC, As and inorganic As are human carcinogens (group 1) causing cancer of the lung, urinary bladder, and skin. Positive associations with kidney, liver, and prostate cancer were found as well [63].

\subsection{Cadmium}

The kidney is the major target organ in $\mathrm{Cd}$ toxicity. In addition, $\mathrm{Cd}$ can induce bone demineralization directly or indirectly through renal dysfunction. $\mathrm{Cd}$ is retained in the kidney and liver with an extremely long biological half-life of 10-30 years, making this metal undoubtedly dangerous in the long term. In a non-smoking general population, $\mathrm{Cd}$ exposure is mainly associated with ingestion of cereals and vegetables grown in $\mathrm{Cd}$ polluted soils [64]. In addition, smoking may significantly contribute to Cd intake; smokers were reported to have 4-5 times higher Cd blood levels than non-smokers [65]. According to an EFSA report for the European population, vegetarians, children, smokers, and people living in contaminated areas may exceed the Cd tolerable weekly intake (TWI) $(2.5 \mu \mathrm{g} / \mathrm{kg}$ bw) approximately two times [64]. The most severe form of chronic Cd toxicity is the disease called itai-itai reported in Toyama, Japan. The disease was officially recognized in 1968 to be caused by consumption of Cd-polluted water and rice. An intervention program targeted at elimination of Cd pollution was introduced in 1980-2012. Nevertheless, the cases of itai-itai disease were reported over subsequent years after removal of $\mathrm{Cd}$ pollution due to the high bioaccumulative features of this metal [66]. Recently, in some Cd-contaminated regions of southern China, the mean grain $\mathrm{Cd}$ concentrations have been found to be in the range of $0.33-0.69 \mathrm{mg} / \mathrm{kg}$, among which $56-87 \%$ of samples exceeded the Chinese food limit for $\mathrm{Cd}(0.2 \mathrm{mg} / \mathrm{kg})$ [67]. The authors of this work have estimated that the dietary Cd exposure of farmers who consume locally grown rice is comparable with that of people living in the region of Japan affected by itai-itai disease [67].

\subsection{Chromium (VI)}

Chromium (VI) is a carcinogenic metal whose principally inhalation-related exposure was associated with lung cancer in workers employed in chromate and chromate pigment factories and chromium electroplating [68]. In addition, an epidemiologic study conducted in the industrial Oinofita region in Greece suggested carcinogenic potential of $\mathrm{Cr}(\mathrm{VI})$ also in oral ingestion. In this study, an elevated $\mathrm{Cr}(\mathrm{VI})$ concentration in drinking water (maximum levels in the range of $41-156 \mu \mathrm{g} / \mathrm{L}$ ) was suggested to contribute to a higher risk of cancers of liver, lungs, and genitourinary organs [69]. $\mathrm{Cr}(\mathrm{VI})$ from anthropogenic sources is a known aquatic pollutant threatening various fish species [70]. Recently, $\mathrm{Cr}$ concentrations in gills of freshwater fishes of the genus Barbus (B. sharpeyi) from the Tigris River, Baghdad, have been reported to be 2.20 and $2.5 \mu \mathrm{g} / \mathrm{g}$ at two sampling sites. These values significantly exceeded the $\mathrm{WHO}$ and $\mathrm{FAO}$ maximum permissible limit of $\mathrm{HMs}$ in freshwater fishes $(0.05 \mu \mathrm{g} / \mathrm{g})[71]$.

\subsection{Nickel}

People may be exposed to nickel (Ni) compounds in occupational settings where $\mathrm{Ni}$ is produced, processed, or used, including mining, smelting and refining, stainless steel production, $\mathrm{Ni}$ alloy production, electroplating, and Ni-Cd battery manufacture [72] Epidemiologic studies found an increased risk of respiratory cancers (nasal and pulmonary) in Ni refinery and smelter workers, and IARC classified Ni compounds as group 1 carcinogens [73]. In addition, $\mathrm{Ni}$ is the most common cause of contact allergy in susceptible persons. $\mathrm{Ni}$ allergy is usually manifested by eczematous dermatitis within the skin area of direct contact with the metal [74]. In addition to occupational exposure sources, Ni-containing 
objects like cell phones [75], jewelry [76], and metallic implants [77] were reported as potential, non-occupational sources of $\mathrm{Ni}$ allergy.

\subsection{Mercury}

There are three forms of mercury $(\mathrm{Hg})$ in the environment: elemental (or metallic, $\left.\mathrm{Hg}^{0}\right) \mathrm{Hg}$, inorganic $\mathrm{Hg}$ compounds, and organic $\mathrm{Hg}$ compounds. All these forms are toxic [78]. Elemental $\mathrm{Hg}$ is a silver-colored heavy metal occurring in its liquid state at room temperature. It is present in such devices as older fever thermometers, fluorescent bulbs, dental amalgams, and jewelry items (e.g., some necklaces from Mexico) [79,80]. Mercurycontaining devices are regarded as potential non-occupational sources of metallic $\mathrm{Hg}$ exposure, since they release metallic $\mathrm{Hg}$ in the form of toxic odorless vapor when broken or heated. Metallic $\mathrm{Hg}$ poisoning cases with mild to death-threatening health symptoms were reported upon inhalation exposure to $\mathrm{Hg}$ vapors from vacuumed or heated metallic $\mathrm{Hg}$. The poisoning symptoms included acute (e.g., cough, dyspnea, chest pain) and chronic effects (e.g., rash, tremor, and weight loss) (reviewed by Caravati et al. [80]). As reviewed by Park and Zheng [78], inorganic $\mathrm{Hg}$ is used as a skin lightening ingredient of cosmetic creams, and cases of $\mathrm{Hg}$ poisoning from these products were reported in Africa, Europe, the US, Mexico, Australia, and China. The toxic effects developing after dermal exposure to inorganic $\mathrm{Hg}$ included fatigue, irritability, headaches, insomnia, burning sensations, and depression [78]. Organic $\mathrm{Hg}$, i.e., ethylmercury (EtHg) used as a preservative (thimerosal), is still present in vaccines for pregnant women, infants, and children in developing countries. Although vaccines contain a very low dose of this compound, which should not be toxic according to $\mathrm{WHO}$, their safety is questioned by some researchers [81]. Another organic $\mathrm{Hg}$ is methylmercury $(\mathrm{MeHg}$ ), which is contained in contaminated seafood (fish and marine mammals) and rice grown in mercury-polluted areas of China [12]. Methylmercury is an established environmental neurotoxicant ranked as the most toxic form among $\mathrm{Hg}$ compounds $(\mathrm{MeHg}>\mathrm{EtHg}>\mathrm{Hg}$ ) [82].

\section{Absorption, Metabolism, and Bioavailability of Epigallocatechin Gallate}

EGCG is mainly absorbed intestinally, in the jejunum and the ileum, via passive diffusion, including paracellular and transcelullar diffusions through epithelial cells [40,83]. Following absorption, EGCG is present in plasma mostly in an unchanged free (unconjugated) form [84,85]. From circulation, EGCG can be distributed to other tissues in the body and has been found in the liver, kidney, spleen, lung, and brain [86]. EGCG was also detected in fetuses and placenta of pregnant rats [40]. In the liver and intestine, EGCG is metabolized through methylation to $4^{\prime \prime}$-O-methyl-EGCG and $4^{\prime}, 4^{\prime \prime}$-di-O-methyl-EGCG [87]. It can also undergo glucuronidation or sulfation [88]. In addition, nonabsorbed EGCG can also be hydrolyzed by intestinal microflora producing epigallocatechin (EGC) and gallic acid; next, EGC degrades to ring-fission products [39]. A ring-fission metabolite 5-(5'hydroxyphenyl)- $\gamma$-valerolactone in a conjugated form was identified in urine of rats following oral administration of radioactive EGCG [89]. Other ring-fission metabolites, namely 5-( $3^{\prime}, 4^{\prime}, 5^{\prime}$-trihydroxyphenyl)- $\gamma$-valerolactone, 5-(3', $4^{\prime}$-dihydroxyphenyl)- $\gamma$-valerolactone, and 5-( $3^{\prime}, 5^{\prime}$-dihydroxyphenyl)- $\gamma$-valerolactone, were detected in human urine after ingestion of pure EGCG [90]. In rats, $77 \%$ of the [4- $\left.{ }^{3} \mathrm{H}\right]$-EGCG dose was excreted in the bile and only $2 \%$ of the dose was found in urine, which shows that bile is the major EGCG excretion route [91].

The poor oral bioavailability of EGCG is largely caused by its poor intestinal stability and absorption. EGCG is chemically very unstable in the intestinal pH conditions [92]. For example, Zou et al. [93] observed that the residual EGCG content in an EGCG solution dropped from $97.9 \%$ to $3.4 \%$ after $1.5 \mathrm{~h}$ incubation in simulated intestinal fluid (weakly alkaline $\mathrm{pH}$ ). As mentioned above, EGCG is also prone to degradation by intestinal microflora. Additionally, both the poor intestinal transport of EGCG related to passive diffusion and the active efflux of EGCG back into the lumen caused by ATP-dependent efflux proteins (multidrug resistance related proteins MRP1 and MRP2) contribute to the low intestinal 
absorption of this catechin [92]. Thus, only a small part of ingested EGCG can reach the bloodstream and can be distributed to other tissues. For example, as reported by Nakagava and Miyazawa [94], EGCG concentrations in fasted plasma were $1047 \mathrm{ng} / \mathrm{mL}$ in rats and $156 \mathrm{ng} / \mathrm{mL}$ in humans, which represented only $0.012 \%$ and $0.32 \%$ of ingested EGCG, respectively. Another study reported that the mean peak plasma concentration of EGCG in humans was $77.9 \mathrm{ng} / \mathrm{mL}(0.17 \mu \mathrm{M})$ after taking a single oral dose of green tea solid (containing $195 \mathrm{mg}$ of EGCG) dissolved in $200 \mathrm{~mL}$ of water (equivalent of two cups of tea) [85]. However, human volunteers taking $500 \mathrm{mg}$ of EGCG as capsules (without food) with $100 \mathrm{~mL}$ of water had a maximum plasma EGCG concentration of $824.2 \mathrm{ng} / \mathrm{mL}$ $(1.8 \mu \mathrm{M})$ [95].

EGCG and its metabolites were found to be absorbed in organs and tissues in the body, with the highest concentrations found in the small intestine and colon, as described below. For example, following administration of a single dose of $150 \mathrm{mg} / \mathrm{kg}$ to rats, the highest concentrations of free EGCG were revealed in small intestine and colon, reaching the values of 4.75-24.41 nmol/g. Free EGCG was also found in the liver, kidney, spleen, lung, and brain at the levels of $0.1-1 \mathrm{nmol} / \mathrm{g}$ [86]. In another study, the authors showed that after administration of EGCG (500 mg/ $\mathrm{kg}$ bw, orally) to rats, the EGCG concentrations reached the values of $12.3 \mathrm{nmol} / \mathrm{mL}$ in the plasma, $48.4 \mathrm{nmol} / \mathrm{g}$ in the liver, $0.5 \mathrm{nmol} / \mathrm{g}$ in the brain, $565 \mathrm{nmol} / \mathrm{g}$ in the small intestine, and $68.6 \mathrm{nmol} / \mathrm{g}$ in the colon [96]. Additionally, ring-fission metabolites of microbial EGCG degradation were present in the plasma [39]. The ring-fission metabolites of catechins were shown to contribute largely to the bioavailability of flavan-3-ols in humans [97]. They exhibited cytoprotective activities including antioxidant and anti-inflammatory effects and were therefore suggested to contribute to the EGCG-mediated biological activities [39].

\section{Mechanistic Considerations of the Protective Effects of EGCG against HM Toxicity}

The focus in this review is placed on experimental studies that have tested EGCG in animal and cell culture models as a potential antidote against HM toxicities. Potentially eligible studies were identified by searching Pubmed, Scopus, and additional manual search through references of previous papers. The following search terms were used: [(heavy metals) or (lead) or (arsenic) or (cadmium) or (mercury) or (nickel) or (chromium)] AND [(epigallocatechin gallate) or (EGCG)]. The collected studies and their results are described in Table 2 (animal data) and Table 3 (cell culture studies). Most of them prove the beneficial effects of EGCG in the treatment of HM poisoning. Considering the intrinsic antioxidant properties of EGCG, several mechanisms through which EGCG may alleviate the adverse actions of HMs have been suggested, as described below. 
Table 2. Summary of animal studies evaluating EGCG effects on HM-induced toxicity.

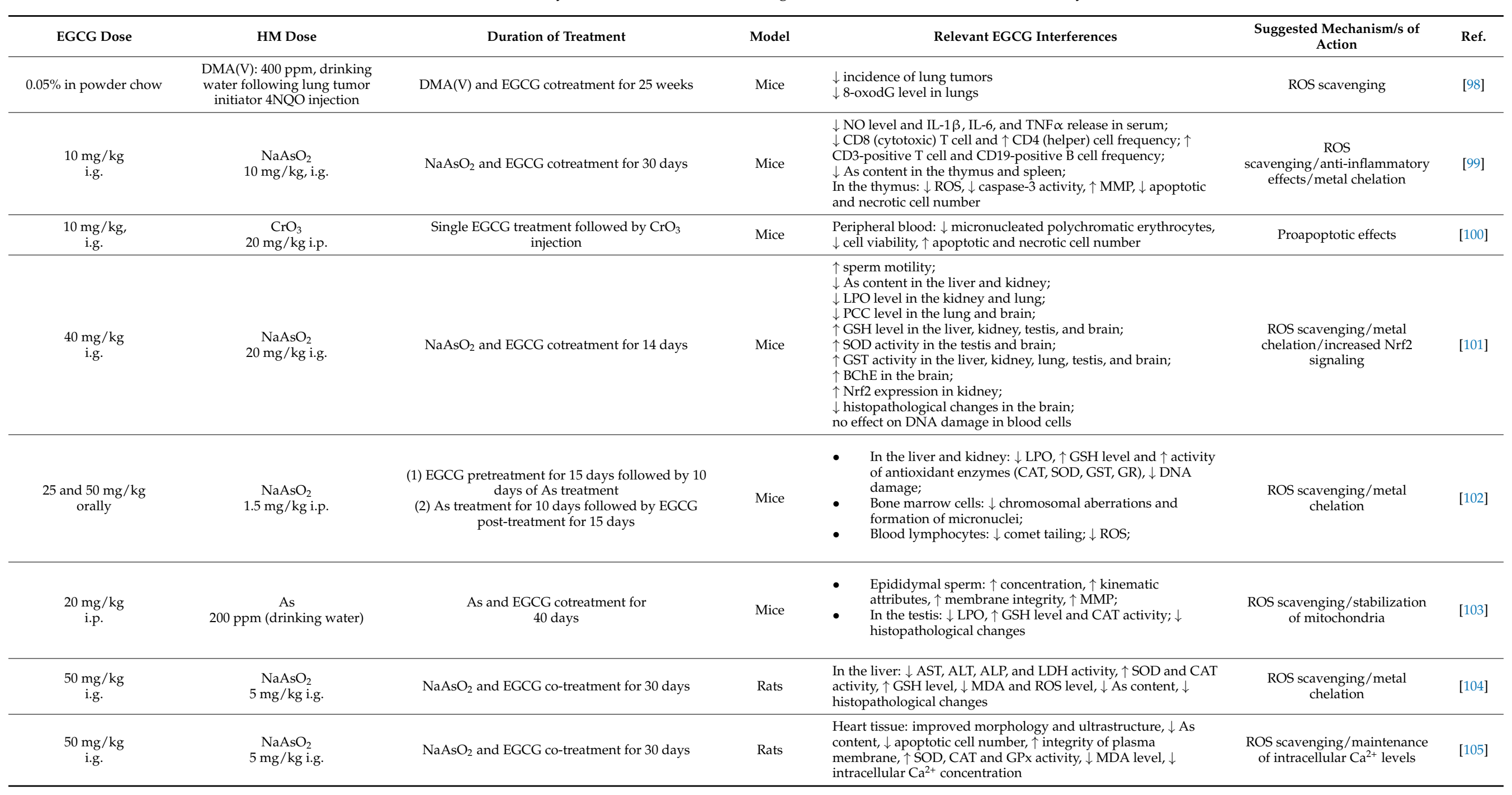


Table 2. Cont.

\begin{tabular}{|c|c|c|c|c|c|c|}
\hline EGCG Dose & HM Dose & Duration of Treatment & Model & Relevant EGCG Interferences & $\begin{array}{l}\text { Suggested Mechanism/s of } \\
\text { Action }\end{array}$ & Ref. \\
\hline $\begin{array}{l}100 \text { and } 200 \mathrm{mg} / \mathrm{kg} \\
\text { i.g. }\end{array}$ & $\begin{array}{c}\mathrm{CdCl}_{2} \\
250 \mathrm{mg} / \mathrm{L} \text { in (drinking water) }\end{array}$ & $\mathrm{CdCl}_{2}$ and EGCG cotreatment for 16 weeks & Rats & $\begin{array}{l}\downarrow \text { blood urea nitrogen and serum creatinine; } \\
\text { in the kidneys: improved morphology, } \downarrow \text { collagen deposition } \\
\text { and fibrosis, } \downarrow \text { TGF- } \beta 1 \text { and p-Smad3 level, } \uparrow \text { GSH level, } \uparrow \text { SOD } \\
\text { and GPx activity, } \downarrow \text { MDA and NO level, } \downarrow \text { miR-21 and miR-192 } \\
\text { level and } \uparrow \mathrm{miR}-29 \mathrm{a} / \mathrm{b} / \mathrm{c} \text { level }\end{array}$ & $\begin{array}{l}\text { ROS } \\
\text { scavenging/anti-inflammatory } \\
\text { effects/modulation of } \\
\text { microRNA levels }\end{array}$ & [106] \\
\hline $\begin{array}{l}10,25 \text {, and } 50 \mathrm{mg} / \mathrm{kg} \\
\text { i.p. }\end{array}$ & $\begin{array}{c}\mathrm{Pb} \text { acetate } \\
1090 \text { ppm (drinking water) }\end{array}$ & $\begin{array}{l}\mathrm{Pb} \text { acetate treatment from PND1-20 (via mother's } \\
\text { milk) and PND21-23 (via drinking water) } \\
\text { EGCG cotreatment from PND14-23 }\end{array}$ & Rats (pups) & $\begin{array}{l}\uparrow \mathrm{Pb} \text { in blood; } \\
\text { in the hippocampus: } \uparrow \text { long-term potentiation amplitude in the } \\
\text { CA1 area, } \uparrow \mathrm{GSH} \text { level and SOD activity, } \downarrow \text { MDA level }\end{array}$ & $\begin{array}{l}\text { ROS scavenging } / \text { metal } \\
\text { chelation }\end{array}$ & [107] \\
\hline $\begin{array}{l}80 \mathrm{mg} / \mathrm{kg} \\
\text { i.p. }\end{array}$ & $\begin{array}{c}\mathrm{Pb} \text { acetate } \\
50 \mathrm{mg} / \mathrm{L} \text { (drinking water) }\end{array}$ & $\mathrm{Pb}$ acetate and EGCG cotreatment for 49 days & Rats & $\begin{array}{l}\uparrow \text { sperm motility, } \uparrow \text { relative weight of testis and seminal vesicles, } \\
\uparrow \text { serum testosterone and } 17 \beta \text {-estradiol level, } \\
\text { in the testis: } \uparrow \text { cyp19 (aromatase P450) gene expression, } \uparrow \text { SOD, } \\
\text { CAT, and GPx activity, } \downarrow \text { MDA levels, } \uparrow \text { testicular architecture } \\
\text { and semen picture }\end{array}$ & $\begin{array}{l}\text { ROS scavenging/increased } \\
\text { cyp19 gene expression }\end{array}$ & [108] \\
\hline
\end{tabular}

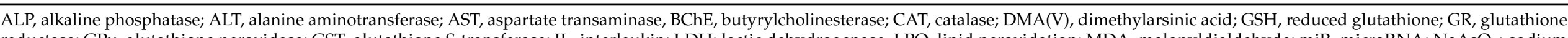

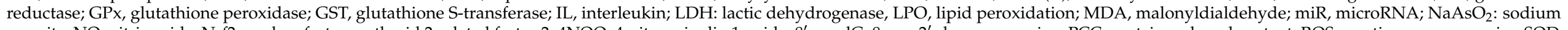

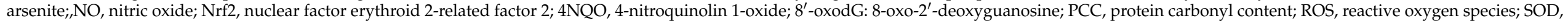
superoxide dismutase; TGF- $\beta 1$, transforming growth factor- $\beta 1$; TNF $\alpha$, tumor necrosis factor- $\alpha \mathrm{c} ; \uparrow$, increased; $\downarrow$, decreased.

Table 3. Summary of studies evaluating EGCG effects on HM-induced toxicity in cell culture models.

\begin{tabular}{|c|c|c|c|c|c|c|}
\hline EGCG Concentration & HM Dose & Duration of Treatment & Cell Type & Effects of EGCG on the Toxicity of HMs & $\begin{array}{l}\text { Suggested Mechanism/s of } \\
\text { EGCG Action }\end{array}$ & Ref. \\
\hline $10 \mu \mathrm{M}$ & $\begin{array}{l}\mathrm{As}_{2} \mathrm{O}_{3} \\
2 \mu \mathrm{M}\end{array}$ & $\begin{array}{l}\mathrm{As}_{2} \mathrm{O}_{3} \text { and EGCG coincubation } \\
\text { for } 3 \text { or } 24 \mathrm{~h}\end{array}$ & $\begin{array}{l}\text { Myeloma cells (RPMI 8226, } \\
\text { IM9), Burkitt's lymphoma cells } \\
\text { (HS-sultan) }\end{array}$ & $\begin{array}{l}\downarrow \text { cell viability; } \uparrow \text { apoptotic cells; } \uparrow \text { intracellular ROS; } \downarrow \text { GSH level; } \downarrow \text { Bcl-2, } \\
\text { Mcl-1, and procaspase- } 3 \text { protein level }\end{array}$ & $\begin{array}{l}\text { Increased ROS } \\
\text { production/decreased GSH } \\
\text { levels/proapoptotic effects }\end{array}$ & [109] \\
\hline $20 \mu \mathrm{M}$ & $\begin{array}{l}\mathrm{NaAsO}_{2} \\
20 \mu \mathrm{M}\end{array}$ & $\begin{array}{l}\mathrm{NaAsO}_{2} \text { and EGCG } \\
\text { coincubation for 3-24 h }\end{array}$ & $\begin{array}{l}\text { Primary bovine aortic } \\
\text { endothelial cells (BAEC) }\end{array}$ & $\begin{array}{l}\downarrow \text { cell viability; } \uparrow \text { number of apoptotic cells; } \uparrow \text { caspase } 3,8 \text {, and } 9 \text { activity; } \uparrow \text { bax } \\
\text { translocation into mitochondria; } \uparrow \text { ROS and MDA level; } \downarrow \text { CAT activity; } \uparrow \text { level } \\
\text { of phosphorylated JNK (p-JNK) }\end{array}$ & $\begin{array}{c}\text { JNK activation/increased ROS } \\
\text { production/proapoptotic } \\
\text { effects }\end{array}$ & [110] \\
\hline $50 \mu \mathrm{M}$ & $\begin{array}{l}\mathrm{NaAsO}_{2} \\
50 \mu \mathrm{M}\end{array}$ & $\begin{array}{l}\mathrm{NaAsO}_{2} \text { and EGCG } \\
\text { coincubation for } 24 \mathrm{~h}\end{array}$ & $\begin{array}{l}\text { Normal human keratinocytes } \\
\text { HaCaT cells }\end{array}$ & $\begin{array}{l}\uparrow \text { ROS and MDA level; } \uparrow \text { 8-OHdG content; } \uparrow \text { DNA damage (comet assay); } ; \\
\text { nuclear and } \uparrow \text { cytosolic expression of Nrf2; } \uparrow \text { nuclear expression of Keap1; } \uparrow \\
\text { protein expression of HO- } 1 \text { and } \gamma \text {-GCSC; } \downarrow \text { SOD, NQO1 and GST activity }\end{array}$ & $\begin{array}{l}\text { Increased ROS } \\
\text { production/modulation of } \\
\text { Nrf2 signaling pathway }\end{array}$ & [111] \\
\hline 30 and $150 \mu \mathrm{M}$ & $\begin{array}{c}\mathrm{CdCl}_{2} \\
30 \text { and } 50 \mu \mathrm{M}\end{array}$ & $\begin{array}{l}\mathrm{CdCl}_{2} \text { and EGCG coincubation } \\
\text { for } 24 \mathrm{~h}\end{array}$ & $\begin{array}{l}\text { Human prostate cancer cell line } \\
\text { PC-3 }\end{array}$ & $\begin{array}{l}\downarrow \text { cell viability; } \\
\text { no complex of EGCG with Cd was formed at pH 7.0 }\end{array}$ & $\begin{array}{l}\text { Modulation of } \mathrm{Ca}^{2+} \text { and } \mathrm{Zn}^{2+} \\
\text { absorption by cells }\end{array}$ & [112] \\
\hline $100 \mu \mathrm{M}$ & $\begin{array}{c}\mathrm{CdCl}_{2} \\
200 \mu \mathrm{M}\end{array}$ & $\begin{array}{l}\mathrm{CdCl}_{2} \text { and EGCG coincubation } \\
\text { for } 2 \mathrm{~h}\end{array}$ & $\begin{array}{l}\text { Mitochondrial-enriched } \\
\text { fractions from rat brain }\end{array}$ & $\begin{array}{l}\uparrow \text { mitochondrial viability; } \downarrow \text { mitochondrial LPO; no effects on nonprotein thiol } \\
\text { levels; formation of Cd:EGCG complex in a 1:1 ratio at } \mathrm{pH} 8.3\end{array}$ & $\begin{array}{l}\text { ROS scavenging/stabilization } \\
\text { of mitochondria/metal } \\
\text { chelation }\end{array}$ & [113] \\
\hline $20 \mu \mathrm{M}$ & $\begin{array}{l}\mathrm{CdCl}_{2} \\
60 \mu \mathrm{M}\end{array}$ & $\begin{array}{l}\mathrm{CdCl}_{2} \text { incubation for } 21 \mathrm{~h} \\
\text { followed by coincubation with } \\
\text { EGCG for } 3 \mathrm{~h}\end{array}$ & $\begin{array}{l}\text { Normal human liver cells } \\
\text { HL-7702 }\end{array}$ & $\begin{array}{l}\uparrow \text { cell viability; } \downarrow \text { apoptosis rate; } \downarrow \text { ROS and MDA levels; } \uparrow \text { MMP; } \downarrow \text { caspase } 3 \\
\text { activity; } \\
\text { EGCG and Cd did not form complexes with each other at neutral } \mathrm{pH} \text { (pH 7.2) }\end{array}$ & $\begin{array}{l}\text { ROS scavenging/stabilization } \\
\text { of mitochondria }\end{array}$ & [114] \\
\hline
\end{tabular}


Table 3. Cont

\begin{tabular}{|c|c|c|c|c|c|c|}
\hline EGCG Concentration & HM Dose & Duration of Treatment & Cell Type & Effects of EGCG on the Toxicity of HMs & $\begin{array}{l}\text { Suggested Mechanism/s of } \\
\text { EGCG Action }\end{array}$ & Ref. \\
\hline $1.5 \mu \mathrm{M}$ & $\begin{array}{l}\mathrm{CdCl}_{2} \\
5 \mu \mathrm{M}\end{array}$ & $\begin{array}{l}1 \mathrm{~h} \text { EGCG pretreatment } \\
\text { followed by } 48 \mathrm{~h} \mathrm{CdCl}_{2} \\
\text { exposure }\end{array}$ & $\begin{array}{l}\text { Rat pheochromocytoma } \\
\text { cell line PC12 }\end{array}$ & $\downarrow$ cell viability; $\downarrow$ cell membrane integrity & $\begin{array}{l}\text { Increased ROS production/cell } \\
\text { membrane disruption }\end{array}$ & [115] \\
\hline $10 \mathrm{mg} / \mathrm{mL}$ & $\begin{array}{c}\mathrm{CH}_{3} \mathrm{HgCl} \\
(\mathrm{MeHg}) \\
2.5,5 \text { and } 10 \mu \mathrm{M}\end{array}$ & $\begin{array}{l}48 \mathrm{~h} \text { EGCG pretreatment } \\
\text { followed by } 24 \mathrm{~h} \mathrm{MeHg} \\
\text { exposure }\end{array}$ & Caenorhabditis elegans & $\begin{array}{ll}\text { - } & \text { EGCG alone (without MeHg): } \uparrow \text { skn- } 1 \text { (Nrf2 ortholog) mRNA levels; } \uparrow \\
\text { gst-4 gene induction, } \uparrow \text { total antioxidant ability } \\
\text { - } \quad \text { EGCG treatment followed by MeHg: } \uparrow \text { LC50 of MeHg (from } 26.1 \text { to } 30.7 \\
\text { M); } \downarrow \text { LPO; } \uparrow \text { locomotion activity; } \downarrow \text { degeneration of DA and } \gamma \text {-GABA } \\
\text { neurons; }\end{array}$ & $\begin{array}{l}\text { Increased Nrf2 signaling } \\
\text { pathway }\end{array}$ & [117] \\
\hline $10 \mu \mathrm{M}$ & $\begin{array}{l}\mathrm{Ni} \mathrm{NPs} \\
2.5-10 \mathrm{\mu g} / \mathrm{cm}^{2}\end{array}$ & $\begin{array}{l}\text { Ni NPs and EGCG } \\
\text { coincubation for } 24 \mathrm{~h}\end{array}$ & Mouse epidermal cells JB6 & $\begin{array}{l}\uparrow \text { cell viability and morphology; } \uparrow \text { G0/G1 phase arrest and } \downarrow \text { G2/M phase } \\
\text { arrest; } ; \downarrow \text { apoptotic cells; } \downarrow \text { intracellular ROS generation; } \downarrow \text { AP-1 and NF-B } \\
\text { activation; } \downarrow \text { protein expression of p-ERK1/2, p-JNK, and p-p38 }\end{array}$ & $\begin{array}{l}\text { ROS } \\
\text { scavenging/anti-inflammatory } \\
\text { effects/modulation of the } \\
\text { MAPK signaling pathway }\end{array}$ & [118] \\
\hline $5,10,15 \mu \mathrm{M}$ & $\begin{array}{c}\mathrm{Pb}^{2+} \\
100 \mu \mathrm{M}\end{array}$ & $\begin{array}{l}\mathrm{Pb}^{2+} \text { and EGCG coincubation } \\
\text { for } 24 \mathrm{~h}\end{array}$ & $\begin{array}{l}\text { Human hepatocellular } \\
\text { carcinoma cell line HepG2 }\end{array}$ & $\uparrow$ cell viability; $\downarrow$ LPO; $\uparrow$ cell membrane fluidity & $\begin{array}{l}\text { ROS scavenging/metal } \\
\text { chelation/stabilization of cell } \\
\text { membranes }\end{array}$ & [119] \\
\hline $50 \mu \mathrm{M}$ & $\begin{array}{c}\mathrm{Pb} \text { acetate } \\
5 \mu \mathrm{M}\end{array}$ & $\begin{array}{l}\mathrm{Pb} \text { acetate and EGCG } \\
\text { coincubation for } 24 \mathrm{~h}\end{array}$ & $\begin{array}{c}\text { SH-SY5Y human } \\
\text { neuroblastoma cells }\end{array}$ & $\downarrow$ apoptosis rate; $\downarrow$ ROS levels; $\downarrow$ caspase 3 activity; $\downarrow$ bax $/$ bcl2 ratio & $\begin{array}{c}\text { ROS scavenging/antiapoptotic } \\
\text { effects }\end{array}$ & {$[120]$} \\
\hline $50 \mu \mathrm{M}$ & $\begin{array}{l}\text { Pb acetate } \\
20 \mu \mathrm{M}\end{array}$ & $\begin{array}{l}\mathrm{Pb} \text { acetate and EGCG } \\
\text { coincubation for } 24 \mathrm{~h}\end{array}$ & Primary hippocampal neurons & $\uparrow$ cell viability; $\downarrow$ ROS levels; $\uparrow$ MMP & $\begin{array}{c}\text { ROS scavenging/stabilization } \\
\text { of mitochondria }\end{array}$ & [107] \\
\hline
\end{tabular}

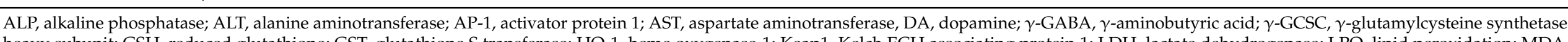

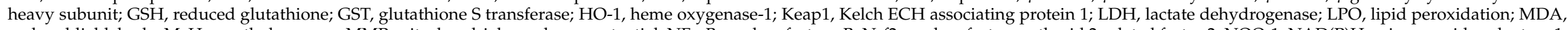

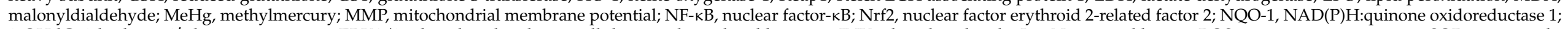

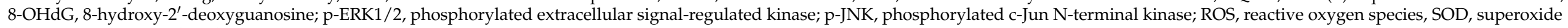
dismutase; $\uparrow$, increased; $\downarrow$, decreased. 


\subsection{Direct Antioxidant Effects of EGCG via Scavenging Cytotoxic Reactive Species and Metal Chelation}

EGCG has the capacity to scavenge free radicals and nonradical reactive species directly. It owes this property to the three vicinal hydroxyl groups on the $\mathrm{B}$ ring and on the gallate moiety (D-ring) [121]. The antioxidative mechanism involves $\mathrm{H}$-atom transfer from the active hydroxyl groups to the free radical (Ar-OH $+\mathrm{R} \cdot \rightarrow \mathrm{ArO} \cdot+\mathrm{RH})$ [122]. In a pure chemical system, EGCG neutralized superoxide anion and hydrogen peroxide and prevented hydroxyl radical-induced DNA damage [43]. EGCG was also shown to be a peroxynitrite scavenger decreasing the nitration of tyrosine [123] and a scavenger of peroxyl radicals [124], hydroxyl radicals [125], hypochlorite [42], and model free radicals, such as DPPH (1,1-diphenyl-2-picryl-hydrazyl) and ABTS (2,2'-azino-bis-[3-ethylbenzothiazoline6-sulfonic acid] diammonium salt) [41]. Another free radical scavenging mechanism of EGCG may involve chelation of iron and other metals through EGCG phenolic groups [40]. EGCG was found to bind metals such as Fe(III) [50,125], Cu(II) [126], Cd [113], and Pb [127] to inactive forms, which may contribute to the reduction of the amounts of available free forms of these metals for prooxidant reactions. For example, due to its $\mathrm{Fe}^{3+}$ binding capacity, EGCG can possibly decrease the labile $\mathrm{Fe}^{3+}$ pool, which prevents $\mathrm{Fe}^{2+}$-based Fenton-type reactions [121].

Recently, studies have shown that EGCG ( 25 and $50 \mathrm{mg} / \mathrm{kg}$ bw for 15 days, orally) protected against As-induced oxidative stress and augmentation in genotoxic indices in the liver and kidney of mice, probably owing to its radical scavenging and metal chelating activities [102]. In another study, EGCG $(10 \mathrm{mg} / \mathrm{kg}$ bw for 30 days through gavage) exhibited a protective effect against As-mediated ROS generation and apoptosis induction in the murine thymus [99]. Similar effects were also reported in cell culture studies in which coincubation with EGCG (5-25 $\mu \mathrm{M}$ for $24 \mathrm{~h}$ ) decreased intracellular ROS levels and protected from $\mathrm{Cr}(\mathrm{VI})$-mediated apoptosis and DNA damage [116]. Similarly, the EGCG cotreatment $(50 \mu \mathrm{M}$ for $24 \mathrm{~h}$ ) decreased $\mathrm{Pb}$-induced oxidative stress and apoptotic cell death [120]. EGCG (100 $\mu \mathrm{M}$ for $2 \mathrm{~h})$ was also found to inhibit Cd-induced dysfunction of mitochondria (from rat brain) through reduction of mitochondrial lipid peroxidation [113]. In addition, the same authors performed spectroscopic analysis of Cd and EGCG interactions, demonstrating the formation of Cd and EGCG complexes in a 1:1 ratio, which was also suggested to contribute to the EGCG-mediated protection of mitochondria. The Cd-EGCG complex was formed at $\mathrm{pH}$ 8.3, and the stability of the complex significantly declined at pH 7.6 [113]. However, the HM chelating properties of EGCG and their role in its radical scavenging activity was questioned by other authors. For instance, An et al. [114] noticed that, although EGCG ( $20 \mu \mathrm{M}$ for $3 \mathrm{~h}$ ) protected cultured liver cells from Cd-induced apoptosis through ROS scavenging, there was no EGCG and Cd binding in their experimental conditions i.e., at neutral $\mathrm{pH}$ of the solution. No Cd-EGCG complex formation at the same $\mathrm{pH}$ value as that used by An et al. [114] was also reported by Yu et al. [112]. The results of these studies showed that the experimental conditions can significantly influence the ability of EGCG to chelate $\mathrm{Cd}^{2+}$.

As mentioned earlier in this review, some $\mathrm{HMs}$ (e.g., $\mathrm{Cd}$ or $\mathrm{Pb}$ ) have a high tendency to accumulate in soft tissues (e.g., kidney or brain) and bones, thus posing a long-term health risk. Certain data in literature support the notion that, probably due to its metal chelating capacity, EGCG may be beneficial in promoting mobilization and excretion of HMs from tissues simultaneously with improvement of oxidative stress markers, as described below. For example, Han et al. [104] have noted that oral application of EGCG $(50 \mathrm{mg} / \mathrm{kg}$ bw for 30 days, intragastric) to rats lowered the As content in the liver, decreased oxidative stress, and protected the liver from histopathological changes caused by As. Similarly, Yu et al. [99] revealed that EGCG (10 mg/ $\mathrm{kg}$ bw for 30 days, intragastric) administration to As-exposed mice decreased As levels in the thymus and spleen and attenuated the prooxidant and proapoptotic effects of As on the thymus. Another study demonstrated the preventive effects of EGCG ( $200 \mathrm{mg} / \mathrm{kg}$ bw once a week for 6 months orally) on bioaccumulation of HMs from a multi-heavy metal mixture in rats [128]. The results of this 
study showed reduced $\mathrm{Hg}$ accumulation in the serum, heart, lung, brain, and liver, a lower $\mathrm{Cd}$ concentration in the liver, spleen, and kidney, and reduced $\mathrm{Cr}$ and $\mathrm{Ni}$ accumulation in the spleen and serum [128]. The researchers suggested that, by promotion of the excretion of HMs from the body, EGCG partly alleviated the joint toxicity of these metals in the serum and liver. In contrast to the above-described results, a study conducted by Yin et al. [107] found that cotreatment with EGCG ( 25 and $50 \mathrm{mg} / \mathrm{kg}$ for 10 days i.p.) of Pb-exposed rat pups increased $\mathrm{Pb}$ levels in the blood. It was suggested that, via complexing $\mathrm{Pb}^{2+}$, EGCG increased its lipophilicity and gastrointestinal Pb absorption. Nevertheless, the EGCG administration in this study was beneficial in protecting the rat brain from $\mathrm{Pb}$-induced oxidative stress [107].

\subsection{Regulation of the Nrf2 Antioxidant Pathway}

Nrf2 (nuclear factor [erythroid-derived 2]-like 2) is mostly known as a transcription factor activating antioxidant genes, including genes of heme oxygenase-1 (HO-1), $\mathrm{NAD}(\mathrm{P}) \mathrm{H}$ :quinone oxidoreductase-1 (NQO1), and superoxide dismutase (SOD1 and SOD2) and genes of enzymes essential for GSH and NADPH synthesis. In addition, Nrf2 stimulates xenobiotic detoxification genes that encode enzymes involved in e.g., glutathione and sulfonate conjugation, glucoronidation, and metallothionein expression. Nrf2 activation is also involved in suppression of inflammatory responses, increased mitochondrial biogenesis and improvement of mitochondrial functions [129]. Since most of the Nrf2-induced responses mentioned above can contribute to HM detoxification, the activation of the Nrf2 protein seems to play an important protective role against adverse HM outcomes. Indeed, as shown by Toyama et al. [130,131], Nrf2-deficient mice $\left(\mathrm{Nrf}^{-/-}\right)$and primary hepatocytes derived from Nrf2-deficient mice were highly sensitive to $\mathrm{MeHg}$ toxicity, in comparison with wild-type mice $\left(\mathrm{Nrf}^{+/+}\right.$) or primary hepatocytes from $\mathrm{Nrf2}^{+/+}$mice.

The activation of Nrf2 at a low to moderate level of oxidative stress is recognized as an initial adaptive response aiming to suppress oxidative stress and maintain cellular homeostasis. However, during high oxidative stress, the Nrf2 pathway is inhibited and more cell destructive inflammatory responses (e.g., NF- $\mathrm{kB}$ activation) are triggered [132]. Thus, the inhibition of Nrf2 in response to HM exposure was indicated as a mechanism contributing to the toxicity and adverse health effects of heavy metals. For instance, treatment with individual $\mathrm{HMs}(\mathrm{Cd}, \mathrm{Pb}, \mathrm{Hg}$, and $\mathrm{Cr})$ has recently been shown to impair the Nrf2 signaling pathway in THP-1 monocytes, which was connected with a decline in lung function, lower plasma GST activity and GSH level in HM-exposed chronic obstructive pulmonary disease patients [133].

EGCG is classified as one of the natural products that can activate the Nrf2 protein [134]. The mechanism of EGCG-mediated Nrf2 activation has been associated with activation of the PI3K (phosphatidylinositol 3-kinase)/Akt pathway and ERK1/2 (extracellular signal-regulated protein kinase 1/2) signaling [135]. It can therefore be suspected that EGCG can prevent HM toxicity via stimulation of Nrf2 antioxidant pathways. Accordingly, EGCG $(10 \mu \mathrm{g} / \mathrm{mL}$ for $48 \mathrm{~h})$ was demonstrated to activate Skn-1, i.e., the Nrf2 ortholog in worms, thereby protecting C. elegans from MeHg toxicity, as shown by Chen et al. [117]. The researchers observed reduced oxidative stress and alleviation of neurotoxic effects, which was confirmed by improved locomotion behaviors and lower numbers of damaged neurons. In another study, EGCG treatment $(40 \mathrm{mg} / \mathrm{kg}$ for 14 days) upregulated Nrf2 expression in the kidney of mice which enhanced antioxidant system and protected from As-induced toxicity [101]. Contrarily, reduced nuclear accumulation of Nrf2 was demonstrated in response to EGCG $(50 \mu \mathrm{M}$ for $24 \mathrm{~h})$ treatment of As-exposed human keratinocytes [111]. This observation was associated with potentiation of As-mediated prooxidant and genotoxic effects, which may suggest excessive oxidative stress that probably suppressed the activation of Nrf2. So far, no further research studies that analyze the association between Nrf2 stimulation and EGCG effects on HMs have been reported. 


\subsection{Regulation of Inflammatory Responses}

Inflammation is a protective mechanism in the body against tissue injury. It involves release of inflammatory mediators, including cytokines and chemokines, and reactive oxygen/nitrogen species (ROS/RNS) as well as attraction of leukocytes to the damaged site in order to eliminate the cause of the injury. The inflammation process is a beneficial response since it allows elimination of tissue damage. However, due to the deregulation or chronic exposure to adverse factors, the ongoing state of inflammation can cause excessive tissue damage and contribute to the development of various diseases, e.g., allergy, asthma, atherosclerosis, autoimmune diseases, and cancer [44,136]. Inflammatory reactions often involve activation of fundamental proinflammatory transcription factors such as the nuclear factor kappaB (NF- $\mathrm{kB}$ ) and activator protein 1 (AP-1). Once activated, NF- $\mathrm{kB}$ and AP-1 move from the cytoplasm to the nucleus and promote the expression of proinflammatory genes, including those coding for cytokines [137,138]. Inflammatory responses induced by HMs frequently play a significant role in the progression of HM-related diseases.

EGCG (10 $\mu \mathrm{M}$ for $24 \mathrm{~h})$ was shown to suppress inflammatory responses, such as activation of NF- $\mathrm{KB}$ and AP-1 in mouse epidermal cells, thereby reducing the cytotoxicity of Ni nanoparticles (Ni NPs) [118]. The authors also demonstrated that EGCG inhibited the upregulation of protein expression of mitogen activated protein kinases (MAPK), namely p-JNK, p-ERK1/2, and p-p38. Since the upregulation of MAPK is very likely to cause activation of NF- $\mathrm{KB}$ and AP-1, EGCG-mediated downregulation of MAPK was suggested as a mechanism involved in the EGCG-mediated inhibition of NF-KB and AP-1 activity, which led to attenuation of Ni NPs-mediated cell toxicity [118]. Yu et al. [99] demonstrated that EGCG $(10 \mathrm{mg} / \mathrm{kg}$ for 30 days by gavage) inhibited As-induced inflammation in mice, as evidenced by a decreased level of nitric oxide $(\mathrm{NO})$ and suppressed release of proinflammatory cytokines (IL-6, TNF $\alpha$, IL-1 $\beta$ ) in serum [99]. In addition, Chen et al. [106] reported that, by targeting the TGF- $\beta 1 / \mathrm{Smad} 3$ signaling pathway, EGCG protected against Cd-induced renal injury and fibrosis in rats. These beneficial effects of EGCG were also accompanied by modulation of renal microRNA levels i.e., decreasing the level of microRNA-21 (miR-21) and miR-192 and increasing the levels of miR-29a/b/c in the Cd-treated rats [106].

\subsection{Regulation of Mitochondrial Functions}

Emerging evidence suggests that mitochondria may play a major role in the beneficial effects of EGCG. As reviewed by Oliveira et al. [139], EGCG may affect diverse mitochondrial functions related to mitochondrial biogenesis, bioenergetics (e.g., ATP synthesis), alterations in cell cycle, and the mitochondrial-dependent apoptotic pathway. A clear participation of mitochondria in the biological actions of EGCG was evidenced by Schroeder et al. [140]. The researchers demonstrated that as much as $90-95 \%$ of EGCG accumulated in the mitochondria of rat cerebellar granule neurons (CGNs) and protected these cells only from those toxic stimuli that induced apoptosis through mitochondrial oxidative stress. In this experimental model, EGCG (10 and $20 \mu \mathrm{M}$, for $24 \mathrm{~h})$ protected CGNs from apoptosis induced by such mitochondrial oxidative stressors as HA14-1 (Bcl-2 inhibitor), tert-butylhydroperoxide (generator of $\mathrm{H}_{2} \mathrm{O}_{2}$ ), and SIN-1 (generator of peroxinitrite). On the other hand, EGCG (5, 10, or $20 \mu \mathrm{M}$ for $24 \mathrm{~h}$ ) did not protect CGNs from proapoptotic insults that are independent of oxidative stress such as proteasome inhibitor (MG132) or trophic factor withdrawal. The authors suggested that accumulation of EGCG in mitochondria, free radical scavenging, and transition metal chelating capabilities were critical in the EGCG-mediated protection of mitochondria in CGNs. Simultaneously, they suggested that the protective effects of EGCG on mitochondria may be cell type specific or stimulus specific and other mechanisms of EGCG may be induced in other cell types [140].

Some studies conducted with various experimental models were focused on the EGCG effects on mitochondria following HM exposure. Some of these studies have already been mentioned in this review in the context of free radical scavenging and metal chelating capabilities of EGCG. An example is the report by Abib et al. [113], who showed the protective activity of EGCG (100 $\mu \mathrm{M}$ for $2 \mathrm{~h}$ ) against Cd-induced impairment of mitochondria 
present in mitochondrial-enriched fractions from rat brain. Another study reported by An et al. [114] demonstrated that, through its radical scavenging properties, EGCG (20 $\mu \mathrm{M}$ for $3 \mathrm{~h}$ ) was effective against collapse of the mitochondrial membrane potential and mitochondrial apoptotic pathway caused by $\mathrm{Cd}$ in normal human liver cells. In an in vivo experimental model, EGCG administration $(20 \mathrm{mg} / \mathrm{kg}$ for 40 days i.p.) to As-exposed mice reduced oxidative stress and restored mitochondrial membrane potential in spermatozoa, thereby contributing to improvement of sperm quality [103]. Some mechanisms through which EGCG may exert its protective effects on mitochondria during HM exposure can be derived from the study conducted by Pan et al. [141]. These authors used a mitochondrial fraction isolated from the kidney of mice exposed to platinum-containing cisplatin. They demonstrated that EGCG (100 mg/kg i.p. for 2 days) ameliorated mitochondrial oxidative/nitrative stress and improved the activities of mitochondrial respiratory enzyme complex activities (NADH dehydrogenase activity, succinate dehydrogenase activity, and cytochrome oxidase activity) and the activities of mitochondrial antioxidant enzymes i.e., manganese superoxide dismutase (MnSOD) and glutathione peroxidase (GPx). This led to reduction of cisplatin-mediated renal injury [141].

Overall, EGCG was found to elicit protective effects on mitochondria during HM exposure in different experimental models through reducing oxidative stress, preserving mitochondrial membrane potential, and enhancing mitochondrial antioxidant and respiratory functions. It is plausible that, through its property of accumulation in mitochondria, EGCG may act as an antioxidant within these organelles, protecting them from HM-induced injury.

The mechanisms of the EGCG protective action relevant to the toxicological pathology of HMs are summarized in Figure 2.

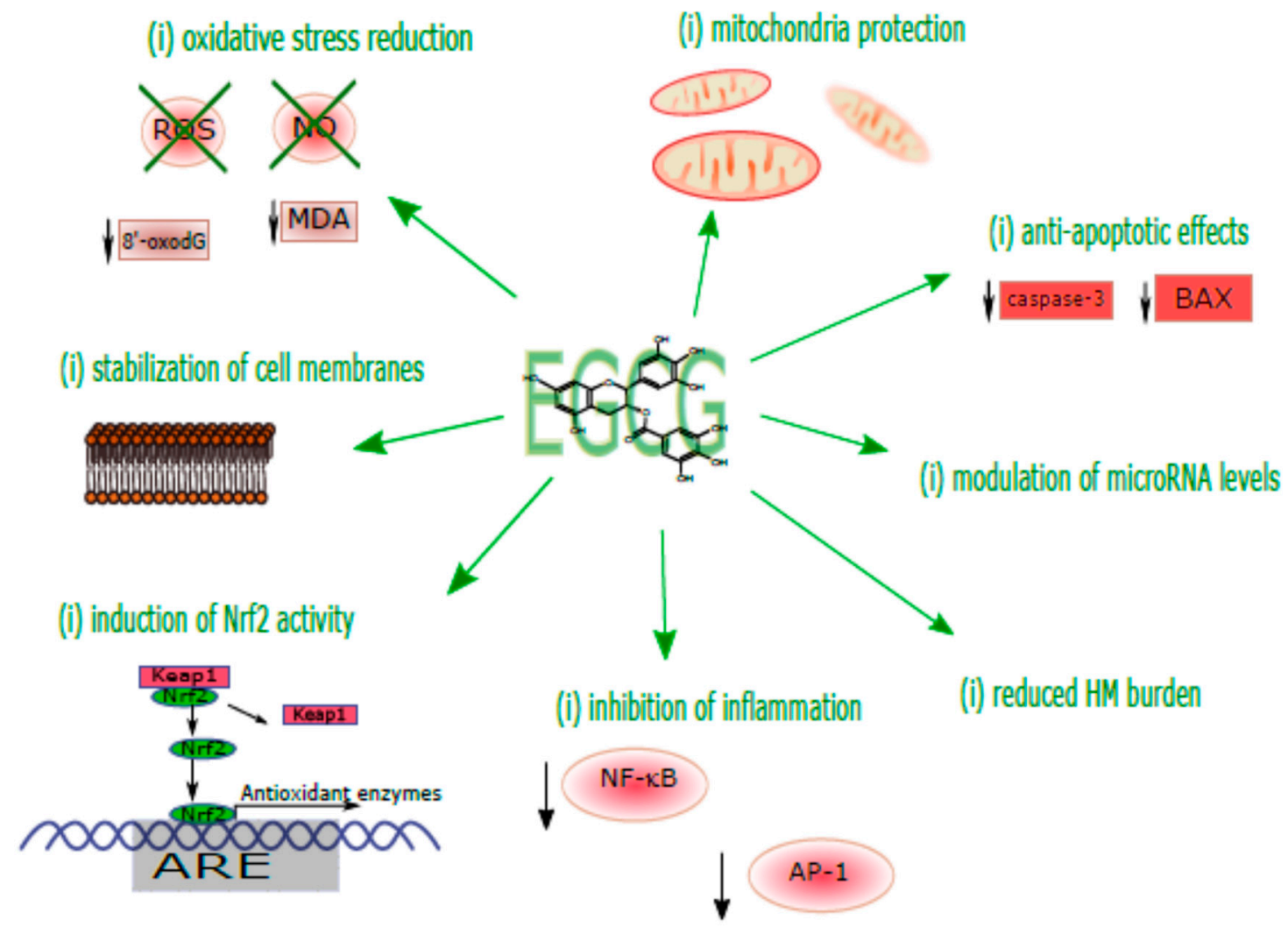

Figure 2. Major protective mechanisms observed in EGCG effects on HM toxicity in experimental studies. AP-1, activator protein 1; ARE, antioxidant response element; Keap1, Kelch-like ECH-associated protein 1; MDA, malondialdehyde; NF- $\mathrm{kB}$, nuclear factor-kB; NO, nitric oxide; Nrf2, nuclear factor erythroid 2-related factor 2; 8'-oxodG, 8-oxo-2'-deoxyguanosine; ROS, reactive oxygen species; $\downarrow$, decreased. 


\section{Toxic Effects Triggered by EGCG during HM Exposure}

Although the majority of studies presented in Tables 2 and 3 proved the beneficial effects of EGCG on HM toxicity, some studies especially from cell culture models have found that EGCG may also exert converse actions and potentiate the harmful outcomes of HM exposure. For instance, EGCG ( $50 \mu \mathrm{M}$ for $24 \mathrm{~h}$ ) significantly increased the prooxidant and genotoxic effects of arsenite in $\mathrm{HaCaT}$ cells [111]. The exact mechanism was not examined by the authors, but it may be explained by the oxidation of EGCG in the cell culture conditions resulting in the formation of ROS and toxic EGCG metabolites. For example, one study reported that, in in vitro conditions in Tris- $\mathrm{HCl}$ buffer (at $\mathrm{pH}$ 7.2), EGCG underwent degradation to form several oxidation products, including EGCG quinone, EGCG dimer quinone, and EGCG dimers [142]. The authors proposed a mechanism of chain reactions of EGCG autooxidation, during which EGCG was oxidized by molecular oxygen to produce ROS and several unstable metabolites with EGCG quinone as the key intermediate. The ROS and EGCG degradation products were suggested to provoke various cellular effects. It is uncertain however whether such reactions can occur in vivo [142]. In addition, through its ability to reduce iron ions from $\mathrm{Fe}^{3+}$ to $\mathrm{Fe}^{2+}$, high doses of EGCG may accelerate Fenton reactions and generation of hydroxyl radicals [43]. Nakazato et al. [109] reported that EGCG (10 $\mu \mathrm{M}$ for $24 \mathrm{~h})$ significantly enhanced $\mathrm{As}_{2} \mathrm{O}_{3}$ induced apoptosis in human malignant B-cell lines, including myeloma cells (RPMI8226) and Burkitt's lymphoma cells (HS-sultan). Moreover, the combination of EGCG (10 $\mu \mathrm{M}$ for $3 \mathrm{~h}$ ) and $\mathrm{As}_{2} \mathrm{O}_{3}$ caused depletion of the intracellular GSH level and enhancement of intracellular ROS levels $\left(\mathrm{O}_{2}{ }^{-}\right.$and $\left.\mathrm{H}_{2} \mathrm{O}_{2}\right)$ in HS-sultan and myeloma cells (IM9 cells). The depletion of GSH and higher levels of ROS were suggested as the main mechanism responsible for the increased apoptosis induction observed during the combined EGCG and $\mathrm{As}_{2} \mathrm{O}_{3}$ treatment [109]. In another study, Kim et al. [110] demonstrated the mechanism by which EGCG made primary-cultured bovine aortic endothelial cells (BEAC) more prone to arsenite-induced toxicity. In this study, EGCG and arsenite combined at nontoxic doses $(20 \mu \mathrm{M})$ activated the JNK pathway, which decreased the activity of catalase leading to increased ROS production, triggering Bax translocation into the mitochondria, and activating proapoptotic enzymes, which consequently resulted in induction of apoptotic cell death [110]. Other mechanisms that may also contribute to toxicity of high doses of EGCG include high affinity of EGCG for lipid bilayers of cell membranes $[143,144]$ as well as EGCG-induced uncoupling of mitochondrial oxidative phosphorylation and damage to the outer mitochondrial membrane [145].

Very recently, Bondad et al. [115] found that low dose of EGCG $(1.5 \mu \mathrm{M})$ significantly increased the adverse effects of $\mathrm{Cd}$ on cell viability and membrane integrity in neural PC12 cells. The authors could not explain the mechanism of the EGCG effects on Cd toxicity, however, EGCG may lack antioxidant activity in certain cell lines, irrespective of its dose, as demonstrated by Elbling et al. [146]. These researchers showed that EGCG at concentration ranges between 0.01 and $50 \mu \mathrm{M}$ was not able to inhibit $\mathrm{H}_{2} \mathrm{O}_{2}$-induced ROS generation and genotoxicity in human promyelocytic leukemic HL60 cells. In this study, EGCG administered at higher but physiologically relevant concentrations $(1 \mu \mathrm{M}$ and higher) enhanced the $\mathrm{H}_{2} \mathrm{O}_{2}$ genotoxic effects and, starting from $10 \mu \mathrm{M}$, increased $\mathrm{H}_{2} \mathrm{O}_{2}$-dependent oxidative stress induction [146].

Overall, EGCG may potentiate the toxic effects of HMs, and these were observed mostly in cell culture studies. The adverse effects of EGCG were observed both in cancerous and noncancerous cell lines. In addition, there is a wide range of EGCG doses that can enhance the harmful action of HMs in vitro spanning from $1.5 \mu \mathrm{M}$ (as observed in the study conducted by Bondad [115]) to $50 \mu \mathrm{M}$ (as observed by Sarkar et al. [111]). As mentioned above, many different mechanisms may be involved in the adverse actions of EGCG during HM exposure. Nonetheless, the low stability of EGCG in solutions and its tendency to autooxidation resulting in ROS formation was suggested as an artifact that may significantly influence the EGCG effects in in vitro conditions $[147,148]$. For example, 1 mM EGCG was found to induce generation of 90 and $141 \mu \mathrm{M} \mathrm{H}_{2} \mathrm{O}_{2}$ in Dulbecco's Modified 
Eagle's Medium (DMEM) and DMEM/F12 culture medium, respectively. In this study, transition metals present in cell culture media (e.g., $\mathrm{Fe}$ and $\mathrm{Cu}$ ) were suggested to catalyze EGCG autooxidation and contribute to $\mathrm{H}_{2} \mathrm{O}_{2}$ production [147]. Therefore, it is important to verify the ability of tested concentrations of EGCG to induce $\mathrm{H}_{2} \mathrm{O}_{2}$ production in examined cell culture conditions.

\section{Potential Obstacles in the Use of EGCG in HM Intoxication Treatment}

The low bioavailability of EGCG is generally regarded as the main impediment in the use of EGCG for the therapy of various diseases, since it hinders the achievement of therapeutic concentration levels of EGCG in the target tissues. Different factors diminish EGCG bioavailability, in particular its poor intestinal stability and low absorption through the intestinal gut wall. In addition, the intestinal and liver-mediated extensive metabolism of EGCG (methylation, glucuronidation, and sulfation) and microbial-mediated degradation in the colon also influence the utilization of EGCG $[83,92]$. There have also been reports on inter-individual variations of EGCG plasma concentrations after oral administration of GT extracts (150 mg EGCG) twice daily (for 5 days) among 84 healthy subjects. On the 5 th day of oral administration, the plasma area under the curve (AUC) of EGCG ranged from 360.8 to $1576.5 \mathrm{~h} * \mu \mathrm{g} / \mathrm{L}$ and the elimination half-lives were in the range of $1.8-3.8$ $\mathrm{h}$, as measured by their 5 th to 95th percentiles [149]. The authors suggested that inherent genetic variations in genes coding for drug transporters, namely multidrug resistanceassociated protein (MRP) 2 and organic anion-transporting polypeptide (OATP) 1B1, could partly influence the variability in catechin plasma concentrations [149]. Different strategies have been suggested to increase EGCG bioavailability. The use of nanocarriers as EGCG delivery systems is being intensively investigated, as it contributes to improvement of intestinal stability and absorption of EGCG. For example, casein micelles were suggested as protective nanocarriers for EGCG in food products [150]. Nanoliposome encapsulation of EGCG effectively improved EGCG stability in simulated intestinal fluid and slowed down the degradation rate of in vitro antioxidant activity of EGCG [93]. EGCG-loaded chitosan-tripolyphosphate nanoparticles improved oral absorption of EGCG in mice, as evidenced by the increased accumulation of EGCG in the stomach and jejunum and the increased plasma concentration of EGCG [151]. Other techniques proposed to increase EGCG bioavailability include molecular modification of phenolic hydroxyl groups of EGCG (reviewed by Dai et al. [92]) and coadministration of EGCG with other food ingredients such as sucrose and ascorbic acid [152].

Furthermore, it is worth indicating that although the oral bioavailability of EGCG and other catechins is low, studies suggest that the concentrations of EGCG in certain conditions such as fasting or repeated dosing (administration) can reach toxic values at which EGCG can induce adverse health effects [153]. Therefore, another problem to solve is to establish safe EGCG dose levels allowing efficacious treatment of HM toxicity without the risk of adverse side effects. Concerns over the safe EGCG dosing during the treatment of various diseases have already been raised by some authors. For example, via comparison of different animal studies, Wang et al. [154] concluded that some of the efficacious (or protective) doses of EGCG and toxic doses of this polyphenol are very close or even overlap. For example, intraperitoneal doses of EGCG ( $50-75 \mathrm{mg} / \mathrm{kg}$ for 1-56 days) that were shown to be protective against brain or liver damage in mice were close to those which induced hepatotoxicity $(100 \mathrm{mg} / \mathrm{kg}$, single i.p. injection) in the same animal model. With regard to HM treatment, animal data showed that the oral doses of EGCG protecting against HMs were in the range of $10-50 \mathrm{mg} / \mathrm{kg}$ (for 1-30 days) in mice and $50-200 \mathrm{mg} / \mathrm{kg}$ (for 30-112 days) in rats. For comparison, Table 4 summarizes some literature data on the toxic effects of EGCG and EGCG-containing preparations administered through the oral or i.p. route in rodents. Thus, it was evidenced that, for example, oral administration of GT extract containing $242 \mathrm{mg}$ EGCG/ $\mathrm{kg}$ (for 14 weeks) induced nasal toxicity in rats [155]. This dose was close to a dose of EGCG ( $200 \mathrm{mg} / \mathrm{kg}$ for 16 week, orally) that proved to be protective against $\mathrm{Cd}$ renal toxicity in rats [106]. With regard to EGCG treatment via the 
i.p. route, there is one study in which the EGCG dose $(80 \mathrm{mg} / \mathrm{kg} / \mathrm{d}$ for 49 days) protecting against $\mathrm{Pb}$-induced damage to rat testes [108] was not far from an EGCG dose (108 mg/kg, a single i.p. treatment), that was found to induce toxic effects in the liver of rats [156]. However, some EGCG doses protecting against HM toxicity administered through the oral or intraperitoneal route in mice and rats were much lower than doses reported to cause toxic effects in rodent models. For example, in a study of As-mediated cancer, diet with $0.05 \%$ EGCG was sufficient to protect mice against As carcinogenic effects. This EGCG dose was far from that in a 1\% EGCG diet reported to induce proinflammatory effects in mice [157].

Table 4. Selected literature data on the toxic effects of EGCG and EGCG-containing green tea extracts or preparations in rodents.

\begin{tabular}{|c|c|c|c|c|c|}
\hline EGCG Dose & $\begin{array}{c}\text { Route of } \\
\text { Administration }\end{array}$ & Duration & Animals & Toxic Effects & References \\
\hline $\begin{array}{c}\text { EGCG } \\
100 \mathrm{mg} / \mathrm{kg}\end{array}$ & i.p. & $4 \mathrm{~d}$ & $\begin{array}{l}\text { Swiss albino mice } \\
\text { (diabetic) }\end{array}$ & $\begin{array}{l}\text { Death ( } 60 \% \text { animals); } \uparrow \text { serum cystatin } C \text { and NGAL } \\
\text { (markers of kidney damage) } \\
\text { In the kidney: } \uparrow \text { NADPH oxidase, } \downarrow \text { TAC, GSH, Nrf2, HO- } 1 \text {, } \\
\text { and HSP 90, } \uparrow \text { NF- } \mathrm{KB} \text { and TNF- } \alpha, \uparrow \text { histopathological } \\
\text { changes }\end{array}$ & [158] \\
\hline $\begin{array}{c}\text { EGCG } \\
55 \mathrm{mg} / \mathrm{kg}\end{array}$ & i.p. & $5 \mathrm{~d}$ & Kunming mice & $\begin{array}{l}\downarrow \text { body weight; } \\
\text { in the serum: } \uparrow \text { ALT, AST (markers of liver damage), } \uparrow \\
4 \text {-HNE, IL-2, IL- } 6 \text { and IL-10 }\end{array}$ & [159] \\
\hline $\begin{array}{c}\text { EGCG } \\
50 \mathrm{mg} / \mathrm{kg}\end{array}$ & i.p. & $3 \mathrm{~d}$ & DO mice & $\begin{array}{l}\text { Mild liver injury (0.55-9.94\% liver necrosis) in } 49 \% \text { animals. } \\
\text { Severe liver injury (10-86.8\% liver necrosis) in } 16 \% \text { animals }\end{array}$ & [160] \\
\hline
\end{tabular}

GT extract $62.5,125,250,500$ and $1000 \mathrm{mg} / \mathrm{kg}$ containing 30.3-484 $\mathrm{mg} / \mathrm{kg}$ of EGCG $(48.4 \%)$

\section{i.g}

14 weeks (5
days per days per
week)
B6C3F1/N mice of

- Death, 6 of 10 (क) and 4 of 10 (

GT $/ \mathrm{kg}(484 \mathrm{mg}$ EGCG $/ \mathrm{kg})$

- In the nose, starting from $250 \mathrm{mg} \mathrm{GT} / \mathrm{kg}(121 \mathrm{mg}$ EGCG /kg, f) and $500 \mathrm{mg} \mathrm{GT} / \mathrm{kg}(242 \mathrm{mg}$ EGCG $/ \mathrm{kg}$, ${ }^{2}$ ): nerve atrophy, olfactory epithelium atrophy, olfactory epithelium metaplasia;

- $\quad$ Reproductive toxicity at $500 \mathrm{mg} \mathrm{GT} / \mathrm{kg}$ (242 mg $\mathrm{EGCG} / \mathrm{kg}$ );

- In the liver: centrilobular necrosis (F) and karyomegaly ( $)$ at 1000 GT mg/kg (484 mg EGCG/kg)

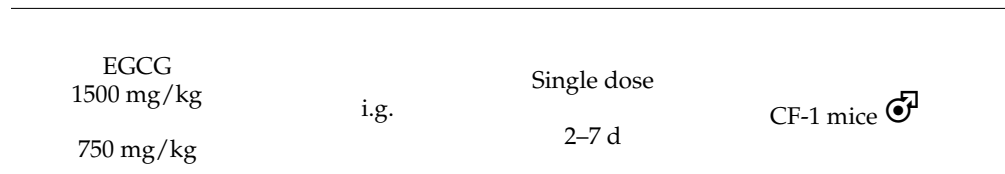

- $\quad 85 \%$ in mortality $(1500 \mathrm{mg} / \mathrm{kg})$ and $75 \%$ in mortality (750 mg/kg);

- In the plasma: $\uparrow$ ALT, MCP-1 and IL-6;

- In the liver: $\uparrow$ apoptosis and necrosis of hepatocytes, $\uparrow 4$-HNE, $\uparrow$ metallothionein I/II

\section{GT extract}

$200 \mathrm{mg} / \mathrm{kg}$

containing 108 $\mathrm{mg} / \mathrm{kg}$ of EGCG

$(54 \%)$ i.p. $\quad$ Single dose SPF rats

- $12 \%$ in mortality ( $), 50 \%$ in mortality ( $)$;

- In the serum: $\uparrow$ AST, ALT and MDA (

- In the liver: $\uparrow$ apoptosis and necrosis of hepatocytes, $\uparrow$ MDA- and TG-positive hepatocytes, $\uparrow$ inflammatory reactions (f)

GT extract $62.5,125,250,500$ and $1000 \mathrm{mg} / \mathrm{kg}$ containing $30.3-484$ $\mathrm{mg} / \mathrm{kg}$ of EGCG $(48.4 \%)$

14 weeks (5
days per
week)

F344/NTac rats
- Reproductive toxicity (\$) at 1000 mg GT/kg (484 mg EGCG/kg);

- In the liver ( $)$ : hepatocyte necrosis, bile duct hyperplasia, oval cell hyperplasia and mitosis at 1000 $\mathrm{mg} \mathrm{GT} / \mathrm{kg}(484 \mathrm{mg}$ EGCG $/ \mathrm{kg})$;

- In the nose starting from $500 \mathrm{mg} \mathrm{GT} / \mathrm{kg}(242 \mathrm{mg}$ $\mathrm{EGCG} / \mathrm{kg}$ ): nerve atrophy and olfactory epithelium metaplasia (f) inflammation ( 
Overall, it is known that antioxidants administered at high doses can have adverse effects, and the data presented above indicate that there may be a narrow boundary between the protective and toxic doses of EGCG. This certainly makes EGCG a challenge for its potential therapeutic application in HM toxicity treatments. Enhancement of the bioavailability of EGCG and reduction of its toxicity through food nanotechnology, structural modification, or beneficial interactions may be a way of overcoming the adverse responses.

\section{Conclusions and Future Directions}

In recent years, many studies have demonstrated the effects of EGCG on HM-induced toxicity in in vitro and in vivo experimental conditions. In general, the in vivo data showed that EGCG can help ameliorate HM toxicity via its ROS scavenging activity, promotion of HM excretion, induction of Nrf2 expression, anti-inflammatory effects, and protection of mitochondria. This protective activity of EGCG was observed in various organs and tissues, including the liver, testis, kidney, and neuronal tissue. Indeed, in spite of its low bioavailability, pharmacokinetic data show that EGCG can be distributed to different internal organ/tissues and cross the blood-brain barrier, thus reaching tissues affected by HM intoxication. The results of the assessment of EGCG effects on HM toxicity from in vitro models are ambiguous. On the one hand, most of them support the in vivo data on the EGCG protective effects and mechanisms induced against HMs. On the other hand, some in vitro results showed potentiation of HM toxicity in the presence of EGCG at similar EGCG concentrations $(1.5-20 \mu \mathrm{M})$, as its beneficial effects were observed. This may be related to the differences in the susceptibility of particular cell types or differences in cell culture conditions, including artifactual generation of hydrogen peroxide or other reactive molecules as a result of autooxidation of EGCG in cell culture media. Noteworthy, the analysis of some in vivo data suggests that indeed the range between nontoxic and toxic EGCG doses may be narrow, which may hamper the EGCG use in the treatment of HM intoxication. This issue certainly needs further study.

In conclusion, future research is warranted in this field of science. The following aspects have been found as worth to be considered:

1. Estimation of optimal EGCG dose ranges which are both safe and effective in the treatment of HM toxicity;

2. Investigation of the indirect mechanisms by which EGCG can modulate HM toxicity, including mitochondrial functions and Nrf2 activity, using different mammalian cells or tissues that are particularly prone to HM intoxication such as the lung, brain, liver, or kidney;

3. Analysis and comparison of the efficacy of native EGCG and nanoEGCG in HM toxicity treatment;

4. Verification of the possible synergistic effect between EGCG and chelation agents on HM toxicity;

5. Investigation of the effects of microbial ring-fission metabolites of EGCG and their contribution to EGCG effects on HM toxicity.

Funding: The APC was funded by the subsidy for science of the John Paul II Catholic University of Lublin, Poland.

Conflicts of Interest: The author declares no conflict of interest.

\section{References}

1. Gavrilescu, M. Behaviour of Persistent Pollutants and Risks Associated with Their Presence in The Environment-Integrated Studies. Environ. Eng. Manag. J. 2009, 8, 1517-1531. [CrossRef]

2. Anyanwu, B.O.; Ezejiofor, A.N.; Igweze, Z.N.; Orisakwe, O.E. Heavy Metal Mixture Exposure and Effects in Developing Nations: An Update. Toxics 2018, 6, 65. [CrossRef]

3. Tóth, G.; Hermann, T.; Szatmári, G.; Pásztor, L. Maps of Heavy Metals in the Soils of the European Union and Proposed Priority Areas for Detailed Assessment. Sci. Total Environ. 2016, 565, 1054-1062. [CrossRef] 
4. Angelovičová, L.; Fazekašová, D. Contamination of the Soil and Water Environment by Heavy Metals in the Former Mining Area of Rudňany (Slovakia). Soil Water Res. 2014, 9, 18-24. [CrossRef]

5. Sodango, T.H.; Li, X.; Sha, J.; Bao, Z. Review of the Spatial Distribution, Source and Extent of Heavy Metal Pollution of Soil in China: Impacts and Mitigation Approaches. J. Health Pollut. 2018, 8, 53-70. [CrossRef] [PubMed]

6. Fasinu, P.; Orisakwe, O.E. Heavy Metal Pollution in Sub-Saharan Africa and Possible Implications in Cancer Epidemiology. Asian Pac. J. Cancer Prev. 2013, 14, 3393-3402. [CrossRef] [PubMed]

7. Serrazina, D.C.; De Andrade, V.L.; Cota, M.; Mateus, M.L.; Aschner, M.; Dos Santos, A.P.M. Biomarkers of Exposure and Effect in a Working Population Exposed to Lead, Manganese and Arsenic. J. Toxicol. Environ. Health A 2018, 81, 983-997. [CrossRef] [PubMed]

8. Romero-Zarazua, M.F.; Sanchez-Salas, J.L.; Quiroz-Alfaro, M.A.; Bandala, E.R.; Méndez-Rojas, M.A. Occupational Exposure to Heavy Metals in a Metal-Mechanical Auto Part Manufacturing Plant in Puebla, Mexico. Int. J. Environ. Health Eng. 2015, 4, 8. [CrossRef]

9. Yang, A.M.; Cheng, Z.Y.; Pu, H.Q.; Cheng, N.; Li, H.Y.; Liu, S.M.; Ding, J.; Li, J.S.; Hu, X.B.; Ren, X.W.; et al. Heavy Metal Assessment among Chinese Nonferrous Metal-Exposed Workers from the Jinchang Cohort Study. Biomed. Environ. Sci. 2017, 30, 530-534. [CrossRef] [PubMed]

10. Hormozi, M.; Mirzaei, R.; Nakhaee, A.; Izadi, S.; Haghighi, J.D. The Biochemical Effects of Occupational Exposure to Lead and Cadmium on Markers of Oxidative Stress and Antioxidant Enzymes Activity in the Blood of Glazers in Tile Industry. Toxicol. Ind. Health 2018, 34, 459-467. [CrossRef]

11. Sung, J.H.; Oh, I.; Kim, A.; Lee, J.; Sim, C.S.; Yoo, C.; Park, S.J.; Kim, G.-B.; Kim, Y. Environmental and Body Concentrations of Heavy Metals at Sites Near and Distant from Industrial Complexes in Ulsan, Korea. J. Korean Med. Sci. 2017, 33. [CrossRef]

12. Li, P.; Feng, X.; Qiu, G. Methylmercury Exposure and Health Effects from Rice and Fish Consumption: A Review. Int. J. Environ. Res. Public Health 2010, 7, 2666-2691. [CrossRef]

13. Substance Priority List I ATSDR. Available online: https://www.atsdr.cdc.gov/spl/index.html (accessed on 31 January 2021).

14. IARC Working Group on the Evaluation of Carcinogenic Risks to Humans. Arsenic, Metals, Fibres and Dusts; International Agency for Research on Cancer: Bethesda, MD, USA, 2012.

15. Amadi, C.N.; Offor, S.J.; Frazzoli, C.; Orisakwe, O.E. Natural Antidotes and Management of Metal Toxicity. Environ. Sci. Pollut. Res. 2019, 26, 18032-18052. [CrossRef] [PubMed]

16. Briffa, J.; Sinagra, E.; Blundell, R. Heavy Metal Pollution in the Environment and Their Toxicological Effects on Humans. Heliyon 2020, 6, e04691. [CrossRef] [PubMed]

17. Patel, M.M.; Hoepner, L.; Garfinkel, R.; Chillrud, S.; Reyes, A.; Quinn, J.W.; Perera, F.; Miller, R.L. Ambient Metals, Elemental Carbon, and Wheeze and Cough in New York City Children through 24 Months of Age. Am. J. Respir. Crit. Care Med. 2009, 180, 1107-1113. [CrossRef] [PubMed]

18. Li, H.; Fagerberg, B.; Sallsten, G.; Borné, Y.; Hedblad, B.; Engström, G.; Barregard, L.; Andersson, E.M. Smoking-Induced Risk of Future Cardiovascular Disease Is Partly Mediated by Cadmium in Tobacco: Malmö Diet and Cancer Cohort Study. Environ. Health 2019, 18, 56. [CrossRef]

19. Nogawa, K.; Suwazono, Y.; Nishijo, M.; Sakurai, M.; Ishizaki, M.; Morikawa, Y.; Watanabe, Y.; Kido, T.; Nakagawa, H. Relationship between Mortality and Rice Cadmium Concentration in Inhabitants of the Polluted Jinzu River Basin, Toyama, Japan: A 26 Year Follow-Up. J. Appl. Toxicol. 2018, 38, 855-861. [CrossRef] [PubMed]

20. Chung, R.T.M. Detoxification Effects of Phytonutrients against Environmental Toxicants and Sharing of Clinical Experience on Practical Applications. Environ. Sci. Pollut. Res. 2017, 24, 8946-8956. [CrossRef]

21. Oh, C.C.; Jin, A.-Z.; Yuan, J.-M.; Koh, W.-P. Fish Intake and Risk of Nonmelanoma Skin Cancer in a Chinese Population: The Singapore Chinese Health Study. Clin. Exp. Dermatol. 2020, 45, 461-463. [CrossRef]

22. Xue, L.; Zhao, Z.; Zhang, Y.; Liao, J.; Wu, M.; Wang, M.; Sun, J.; Gong, H.; Guo, M.; Li, S.; et al. Dietary Exposure to Arsenic and Human Health Risks in Western Tibet. Sci. Total. Environ. 2020, 731, 138840. [CrossRef]

23. Hosoki, M.; Nishigawa, K.; Miyamoto, Y.; Ohe, G.; Matsuka, Y. Allergic Contact Dermatitis Caused by Titanium Screws and Dental Implants. J. Prosthodont. Res. 2016, 60, 213-219. [CrossRef] [PubMed]

24. Engelhart, S.; Segal, R.J. Allergic Reaction to Vanadium Causes a Diffuse Eczematous Eruption and Titanium Alloy Orthopedic Implant Failure. Cutis 2017, 99, 245-249.

25. Mehta, V.; Midha, V.; Mahajan, R.; Narang, V.; Wander, P.; Sood, R.; Sood, A. Lead Intoxication Due to Ayurvedic Medications as a Cause of Abdominal Pain in Adults. Clin. Toxicol. 2017, 55, 97-101. [CrossRef] [PubMed]

26. Nędzarek, A.; Tórz, A.; Karakiewicz, B.; Clark, J.S.; Laszczyńska, M.; Kaleta, A.; Adler, G. Concentrations of Heavy Metals (Mn, $\mathrm{Co}, \mathrm{Ni}, \mathrm{Cr}, \mathrm{Ag}, \mathrm{Pb}$ ) in Coffee. Acta Biochim. Pol. 2013, 60, 623-627. [CrossRef] [PubMed]

27. Borowska, S.; Brzóska, M.M. Metals in Cosmetics: Implications for Human Health. J. Appl. Toxicol. 2015, 35, 551-572. [CrossRef]

28. Blanusa, M.; Varnai, V.M.; Piasek, M.; Kostial, K. Chelators as Antidotes of Metal Toxicity: Therapeutic and Experimental Aspects. Curr. Med. Chem. 2005, 12, 2771-2794. [CrossRef] [PubMed]

29. Flora, S.J.; Pachauri, V. Chelation in Metal Intoxication. Int. J. Environ. Res. Public Health 2010, 7, 2745-2788. [CrossRef] [PubMed]

30. Mazumder, D.N.G. Chapter 4: Diagnosis and Treatment of Chronic Arsenic Poisoning. In United Nations Synthesis Report on Arsenic in Drinking Water; WHO: Geneva, Switzerland, 2000. 
31. Sears, M.E. Chelation: Harnessing and Enhancing Heavy Metal Detoxification-A Review. Sci. World J. 2013, $2013,1-13$. [CrossRef]

32. Li, D.; An, D.; Zhou, Y.; Liu, J.; Waalkes, M.P. Current Status and Prevention Strategy for Coal-Arsenic Poisoning in Guizhou, China. J. Health Popul. Nutr. 2006, 24, 273-276.

33. Winiarska-Mieczan, A. Protective Effect of Tea against Lead and Cadmium-Induced Oxidative Stress-a Review. Biometals 2018, 31, 909-926. [CrossRef]

34. Zwolak, I. Protective Effects of Dietary Antioxidants against Vanadium-Induced Toxicity: A Review. Oxidative Med. Cell. Longev. 2020, 2020, 1490316. [CrossRef] [PubMed]

35. Omidkhoda, S.F.; Razavi, B.M.; Hosseinzadeh, H. Protective Effects of Ginkgo Biloba L. against Natural Toxins, Chemical Toxicities, and Radiation: A Comprehensive Review. Phytother. Res. 2019, 33, 2821-2840. [CrossRef] [PubMed]

36. Maiti, S.; Acharyya, N.; Ghosh, T.K.; Ali, S.S.; Manna, E.; Nazmeen, A.; Sinha, N.K. Green Tea (Camellia Sinensis) Protects Against Arsenic Neurotoxicity via Antioxidative Mechanism and Activation of Superoxide Dismutase Activity. Cent. Nerv. Syst. Agents Med. Chem. 2017, 17, 187-195. [CrossRef] [PubMed]

37. Anacleto, P.; Barbosa, V.; Alves, R.N.; Maulvault, A.L.; Bronze, M.R.; Marques, A. Green Tea Infusion Reduces Mercury Bioaccessibility and Dietary Exposure from Raw and Cooked Fish. Food Chem. Toxicol. 2020, 145, 111717. [CrossRef]

38. Abdelrazek, H.M.A.; Helmy, S.A.; Elsayed, D.H.; Ebaid, H.M.; Mohamed, R.M. Ameliorating Effects of Green Tea Extract on Cadmium Induced Reproductive Injury in Male Wistar Rats with Respect to Androgen Receptors and Caspase-3. Reprod. Biol. 2016, 16, 300-308. [CrossRef] [PubMed]

39. Pervin, M.; Unno, K.; Takagaki, A.; Isemura, M.; Nakamura, Y. Function of Green Tea Catechins in the Brain: Epigallocatechin Gallate and Its Metabolites. Int. J. Mol. Sci. 2019, 20, 3630. [CrossRef]

40. Legeay, S.; Rodier, M.; Fillon, L.; Faure, S.; Clere, N. Epigallocatechin Gallate: A Review of Its Beneficial Properties to Prevent Metabolic Syndrome. Nutrients 2015, 7, 5443-5468. [CrossRef]

41. He, J.; Xu, L.; Yang, L.; Wang, X. Epigallocatechin Gallate Is the Most Effective Catechin Against Antioxidant Stress via Hydrogen Peroxide and Radical Scavenging Activity. Med. Sci. Monit. 2018, 24, 8198-8206. [CrossRef]

42. Grzesik, M.; Naparło, K.; Bartosz, G.; Sadowska-Bartosz, I. Antioxidant Properties of Catechins: Comparison with Other Antioxidants. Food Chem. 2018, 241, 480-492. [CrossRef]

43. Tian, B.; Sun, Z.; Xu, Z.; Hua, Y. Chemiluminescence Analysis of the Prooxidant and Antioxidant Effects of Epigallocatechin-3Gallate. Asia Pac. J. Clin. Nutr 2007, 16 (Suppl. S1), 153-157.

44. Chu, C.; Deng, J.; Man, Y.; Qu, Y. Green Tea Extracts Epigallocatechin-3-Gallate for Different Treatments. Biomed Res. Int. 2017, 2017, 1-9. [CrossRef]

45. Kanwar, J.; Taskeen, M.; Mohammad, I.; Huo, C.; Chan, T.H.; Dou, Q.P. Recent Advances on Tea Polyphenols. Front. Biosci. 2012, 4, 111-131. [CrossRef]

46. Kanlaya, R.; Thongboonkerd, V. Protective Effects of Epigallocatechin-3-Gallate from Green Tea in Various Kidney Diseases. Adv. Nutr. 2019, 10, 112-121. [CrossRef]

47. Singh, N.A.; Mandal, A.K.A.; Khan, Z.A. Potential Neuroprotective Properties of Epigallocatechin-3-Gallate (EGCG). Nutr. J. 2016, 15, 60. [CrossRef] [PubMed]

48. Li, F.; Wang, Y.; Li, D.; Chen, Y.; Qiao, X.; Fardous, R.; Lewandowski, A.; Liu, J.; Chan, T.-H.; Dou, Q.P. Perspectives on the Recent Developments with Green Tea Polyphenols in Drug Discovery. Expert Opin. Drug Discov. 2018, 13, 643-660. [CrossRef] [PubMed]

49. Nanjo, F.; Mori, M.; Goto, K.; Hara, Y. Radical Scavenging Activity of Tea Catechins and Their Related Compounds. BioSci. Biotechnol. Biochem. 1999, 63, 1621-1623. [CrossRef] [PubMed]

50. Ryan, P.; Hynes, M.J. The Kinetics and Mechanisms of the Complex Formation and Antioxidant Behaviour of the Polyphenols EGCg and ECG with Iron(III). J. Inorg. Biochem. 2007, 101, 585-593. [CrossRef] [PubMed]

51. Zhao, J.; Xu, L.; Liang, Q.; Sun, Q.; Chen, C.; Zhang, Y.; Ding, Y.; Zhou, P. Metal Chelator EGCG Attenuates Fe(III)-Induced Conformational Transition of $\alpha$-Synuclein and Protects AS-PC12 Cells against Fe(III)-Induced Death. J. Neurochem. 2017, 143, 136-146. [CrossRef] [PubMed]

52. Jia, G.; Aroor, A.R.; Martinez-Lemus, L.A.; Sowers, J.R. Mitochondrial Functional Impairment in Response to Environmental Toxins in the Cardiorenal Metabolic Syndrome. Arch. Toxicol. 2015, 89, 147-153. [CrossRef] [PubMed]

53. Lead Poisoning and Health. Available online: https://www.who.int/news-room/fact-sheets/detail/lead-poisoning-and-health (accessed on 5 February 2021).

54. ATSDR. Lead $(\mathrm{Pb})$ Toxicity: What is the Biological Fate of Lead in the Body? I ATSDR-Environmental Medicine \& Environmental Health Education-CSEM. Available online: https: / / www.atsdr.cdc.gov/csem/csem.asp?csem=34\&po=9 (accessed on 5 February 2021).

55. Charkiewicz, A.E.; Backstrand, J.R. Lead Toxicity and Pollution in Poland. Int. J. Environ. Res. Public Health 2020, $17,4385$. [CrossRef] [PubMed]

56. Neurogenetic Developmental Disorders I MIT CogNet. Available online: http://cognet.mit.edu/book/neurogeneticdevelopmental-disorders (accessed on 31 January 2021).

57. Hauptman, M.; Bruccoleri, R.; Woolf, A.D. An Update on Childhood Lead Poisoning. Clin. Pediatr. Emerg. Med. 2017, 18, 181-192. [CrossRef] [PubMed] 
58. Preventing Disease through Healthy Environments: Exposure to Lead: A Major Public Health Concern. Available online: https://www.who.int/publications-detail-redirect/WHO-CED-PHE-EPE-19.4.7-eng (accessed on 5 February 2021).

59. Tchounwou, P.B.; Yedjou, C.G.; Patlolla, A.K.; Sutton, D.J. Heavy Metals Toxicity and the Environment. EXS 2012, 101, 133-164. [CrossRef] [PubMed]

60. Natasha; Shahid, M.; Imran, M.; Khalid, S.; Murtaza, B.; Niazi, N.K.; Zhang, Y.; Hussain, I. Arsenic Environmental Contamination Status in South Asia. In Arsenic in Drinking Water and Food; Srivastava, S., Ed.; Springer: Singapore, 2020; pp. 13-39. [CrossRef]

61. Jaishankar, M.; Tseten, T.; Anbalagan, N.; Mathew, B.B.; Beeregowda, K.N. Toxicity, Mechanism and Health Effects of Some Heavy Metals. Interdiscip. Toxicol. 2014, 7, 60-72. [CrossRef]

62. Clemens, S.; Ma, J.F. Toxic Heavy Metal and Metalloid Accumulation in Crop Plants and Foods. Annu. Rev. Plant Biol. 2016, 67, 489-512. [CrossRef] [PubMed]

63. IARC Working Group on the Evaluation of Carcinogenic Risks to Humans. Arsenic and Arsenic Compounds; International Agency for Research on Cancer: Bethesda, MD, USA, 2012.

64. Anonymous. Cadmium in Food-Scientific Opinion of the Panel on Contaminants in the Food Chain. EFSA J. 2009, 7, 980 [CrossRef]

65. Rahimzadeh, M.R.; Rahimzadeh, M.R.; Kazemi, S.; Moghadamnia, A. Cadmium Toxicity and Treatment: An Update. Casp. J. Intern. Med. 2017, 8, 135-145. [CrossRef]

66. Zwolak, I. The Role of Selenium in Arsenic and Cadmium Toxicity: An Updated Review of Scientific Literature. Biol. Trace Elem. Res. 2020, 193, 44-63. [CrossRef]

67. Wang, P.; Chen, H.; Kopittke, P.M.; Zhao, F.-J. Cadmium Contamination in Agricultural Soils of China and the Impact on Food Safety. Environ. Pollut. 2019, 249, 1038-1048. [CrossRef]

68. IARC Working Group on the Evaluation of Carcinogenic Risks to Humans. Chromium (Vi) Compounds; International Agency for Research on Cancer: Bethesda, MD, USA, 2012.

69. Linos, A.; Petralias, A.; Christophi, C.A.; Christoforidou, E.; Kouroutou, P.; Stoltidis, M.; Veloudaki, A.; Tzala, E.; Makris, K.C.; Karagas, M.R. Oral Ingestion of Hexavalent Chromium through Drinking Water and Cancer Mortality in an Industrial Area of Greece-an Ecological Study. Environ. Health 2011, 10, 50. [CrossRef]

70. Velma, V.; Vutukuru, S.S.; Tchounwou, P.B. Ecotoxicology of Hexavalent Chromium in Freshwater Fish: A Critical Review. Rev. Environ. Health 2009, 24, 129-145. [CrossRef]

71. Mensoor, M.; Said, A.M. Determination of Heavy Metals in Freshwater Fishes of the Tigris River in Baghdad. Fishes 2018, 3, 23. [CrossRef]

72. ATSDR-Toxicological Profile: Nickel. Available online: https://www.atsdr.cdc.gov/toxprofiles/tp.asp?id=245\&tid=44 (accessed on 6 February 2021).

73. IARC Working Group on the Evaluation of Carcinogenic Risks to Humans. Nickel and Nickel Compounds; International Agency for Research on Cancer: Bethesda, MD, USA, 2012.

74. Tramontana, M.; Bianchi, L.; Hansel, K.; Agostinelli, D.; Stingeni, L. Nickel Allergy: Epidemiology, Pathomechanism, Clinical Patterns, Treatment and Prevention Programs. Endocr. Metab. Immune Disord. Drug Targets 2020, 20, 992-1002. [CrossRef] [PubMed]

75. Tammaro, A.; Magri, F.; Pigliacelli, F.; Gelormini, E.; Francesca, R.P.; Chello, C.; Persechino, S. Allergic Contact Dermatitis to a Cell Phone. Acta Dermatovenerol. Croat. 2018, 26, 339-340. [PubMed]

76. Mcdonagh, A.J.G.; Wright, A.L.; Cork, M.J.; Gawkrodger, D.J. Nickel Sensitivity: The Influence of Ear Piercing and Atopy. Br. J. Dermatol. 1992, 126, 16-18. [CrossRef]

77. Guntani, A.; Kawakubo, E.; Yoshiga, R.; Mii, S. Metallic Allergy Requiring Removal of Iliac Stent: Report of a Case. Surg. Case Rep. 2020, 6, 82. [CrossRef]

78. Park, J.-D.; Zheng, W. Human Exposure and Health Effects of Inorganic and Elemental Mercury. J. Prev. Med. Public Health 2012, 45, 344-352. [CrossRef]

79. US EPA. How People are Exposed to Mercury. Available online: https://www.epa.gov/mercury/how-people-are-exposedmercury (accessed on 1 February 2021).

80. Caravati, E.M.; Erdman, A.R.; Christianson, G.; Nelson, L.S.; Woolf, A.D.; Booze, L.L.; Cobaugh, D.J.; Chyka, P.A.; Scharman, E.J.; Manoguerra, A.S.; et al. Elemental Mercury Exposure: An Evidence-Based Consensus Guideline for out-of-Hospital Management. Clin. Toxicol. 2008, 46, 1-21. [CrossRef]

81. Dórea, J.G. Low-Dose Thimerosal (Ethyl-Mercury) Is Still Used in Infants' Vaccines: Should We Be Concerned with This Form of Exposure? J. Trace Elem. Med. Biol. 2018, 49, 134-139. [CrossRef]

82. Dórea, J.G.; Farina, M.; Rocha, J.B.T. Toxicity of Ethylmercury (and Thimerosal): A Comparison with Methylmercury. J. Appl. Toxicol. 2013, 33, 700-711. [CrossRef]

83. Cai, Z.-Y.; Li, X.-M.; Liang, J.-P.; Xiang, L.-P.; Wang, K.-R.; Shi, Y.-L.; Yang, R.; Shi, M.; Ye, J.-H.; Lu, J.-L.; et al. Bioavailability of Tea Catechins and Its Improvement. Molecules 2018, 23, 2346. [CrossRef]

84. Clifford, M.N.; van der Hooft, J.J.; Crozier, A. Human Studies on the Absorption, Distribution, Metabolism, and Excretion of Tea Polyphenols. Am. J. Clin. Nutr. 2013, 98 (Suppl. S6), 1619S-1630S. [CrossRef] 
85. Lee, M.-J.; Maliakal, P.; Chen, L.; Meng, X.; Bondoc, F.Y.; Prabhu, S.; Lambert, G.; Mohr, S.; Yang, C.S. Pharmacokinetics of Tea Catechins after Ingestion of Green Tea and (-)-Epigallocatechin-3-Gallate by Humans: Formation of Different Metabolites and Individual Variability. Cancer Epidemiol. Biomarkers Prev. 2002, 11 Pt 1, 1025-1032.

86. Raneva, V.G.; Shimizu, Y.; Shimasaki, H. Antioxidant Activity in Plasma and Tissues Distribution of (-)-Epigallocatechin Gallate after Oral Administration to Rats. J. Oleo Sci. 2005, 54, 289-298. [CrossRef]

87. Lu, H.; Meng, X.; Yang, C.S. Enzymology of Methylation of Tea Catechins and Inhibition of Catechol-O-Methyltransferase by (-)-Epigallocatechin Gallate. Drug Metab. Dispos. 2003, 31, 572-579. [CrossRef] [PubMed]

88. Lu, H.; Meng, X.; Li, C.; Sang, S.; Patten, C.; Sheng, S.; Hong, J.; Bai, N.; Winnik, B.; Ho, C.-T.; et al. Glucuronides of Tea Catechins: Enzymology of Biosynthesis and Biological Activities. Drug Metab. Dispos. 2003, 31, 452-461. [CrossRef]

89. Kohri, T.; Matsumoto, N.; Yamakawa, M.; Suzuki, M.; Nanjo, F.; Hara, Y.; Oku, N. Metabolic Fate of (-)-[4-(3)H]Epigallocatechin Gallate in Rats after Oral Administration. J. Agric. Food Chem. 2001, 49, 4102-4112. [CrossRef] [PubMed]

90. Meng, X.; Sang, S.; Zhu, N.; Lu, H.; Sheng, S.; Lee, M.-J.; Ho, C.-T.; Yang, C.S. Identification and Characterization of Methylated and Ring-Fission Metabolites of Tea Catechins Formed in Humans, Mice, and Rats. Chem. Res. Toxicol. 2002, 15, 1042-1050. [CrossRef]

91. Kohri, T.; Nanjo, F.; Suzuki, M.; Seto, R.; Matsumoto, N.; Yamakawa, M.; Hojo, H.; Hara, Y.; Desai, D.; Amin, S.; et al. Synthesis of (-)-[4-3H]Epigallocatechin Gallate and Its Metabolic Fate in Rats after Intravenous Administration. J. Agric. Food Chem. 2001, 49, 1042-1048. [CrossRef]

92. Dai, W.; Ruan, C.; Zhang, Y.; Wang, J.; Han, J.; Shao, Z.; Sun, Y.; Liang, J. Bioavailability Enhancement of EGCG by Structural Modification and Nano-Delivery: A Review. J. Funct. Foods 2020, 65, 103732. [CrossRef]

93. Zou, L.; Peng, S.; Liu, W.; Gan, L.; Liu, W.; Liang, R.; Liu, C.; Niu, J.; Cao, Y.; Liu, Z.; et al. Improved in Vitro Digestion Stability of (-)-Epigallocatechin Gallate through Nanoliposome Encapsulation. Food Res. Int. 2014, 64, 492-499. [CrossRef]

94. Nakagawa, K.; Miyazawa, T. Chemiluminescence-High-Performance Liquid Chromatographic Determination of Tea Catechin, (-)-Epigallocatechin 3-Gallate, at Picomole Levels in Rat and Human Plasma. Anal. Biochem. 1997, 248, 41-49. [CrossRef]

95. Naumovski, N.; Blades, B.L.; Roach, P.D. Food Inhibits the Oral Bioavailability of the Major Green Tea Antioxidant Epigallocatechin Gallate in Humans. Antioxidants 2015, 4, 373-393. [CrossRef]

96. Nakagawa, K.; Miyazawa, T. Absorption and Distribution of Tea Catechin, (-)-Epigallocatechin-3-Gallate, in the Rat. J. Nutr. Sci. Vitaminol. 1997, 43, 679-684. [CrossRef]

97. Calani, L.; Del Rio, D.; Callegari, M.L.; Morelli, L.; Brighenti, F. Updated Bioavailability and 48 h Excretion Profile of Flavan-3-Ols from Green Tea in Humans. Int. J. Food Sci. Nutr. 2012, 63, 513-521. [CrossRef]

98. Mizoi, M.; Takabayashi, F.; Nakano, M.; An, Y.; Sagesaka, Y.; Kato, K.; Okada, S.; Yamanaka, K. The Role of Trivalent Dimethylated Arsenic in Dimethylarsinic Acid-Promoted Skin and Lung Tumorigenesis in Mice: Tumor-Promoting Action through the Induction of Oxidative Stress. Toxicol. Lett. 2005, 158, 87-94. [CrossRef]

99. Yu, N.-H.; Pei, H.; Huang, Y.-P.; Li, Y.-F. (-)-Epigallocatechin-3-Gallate Inhibits Arsenic-Induced Inflammation and Apoptosis through Suppression of Oxidative Stress in Mice. Cell. Physiol. Biochem. 2017, 41, 1788-1800. [CrossRef]

100. García-Rodríguez, M.D.C.; Montaño-Rodríguez, A.R.; Altamirano-Lozano, M.A. Modulation of Hexavalent Chromium-Induced Genotoxic Damage in Peripheral Blood of Mice by Epigallocatechin-3-Gallate (EGCG) and Its Relationship to the Apoptotic Activity. J. Toxicol. Environ. Health Part A 2016, 79, 28-38. [CrossRef]

101. Singh, G.; Thaker, R.; Sharma, A.; Parmar, D. Therapeutic Effects of Biochanin A, Phloretin, and Epigallocatechin-3-Gallate in Reducing Oxidative Stress in Arsenic-Intoxicated Mice. Environ. Sci. Pollut. Res. Int. 2021, 1-20. [CrossRef]

102. Kaushal, S.; Ahsan, A.U.; Sharma, V.L.; Chopra, M. Epigallocatechin Gallate Attenuates Arsenic Induced Genotoxicity via Regulation of Oxidative Stress in Balb/C Mice. Mol. Biol. Rep. 2019, 46, 5355-5369. [CrossRef]

103. Guvvala, P.R.; Ravindra, J.P.; Rajani, C.V.; Sivaram, M.; Selvaraju, S. Protective Role of Epigallocatechin-3-Gallate on Arsenic Induced Testicular Toxicity in Swiss Albino Mice. Biomed. Pharm. 2017, 96, 685-694. [CrossRef]

104. Han, X.-D.; Zhang, Y.-Y.; Wang, K.-L.; Huang, Y.-P.; Yang, Z.-B.; Liu, Z. The Involvement of Nrf2 in the Protective Effects of (-)-Epigallocatechin-3-Gallate (EGCG) on NaAsO2-Induced Hepatotoxicity. Oncotarget 2017, 8, 65302-65312. [CrossRef] [PubMed]

105. Sun, T.-L.; Liu, Z.; Qi, Z.-J.; Huang, Y.-P.; Gao, X.-Q.; Zhang, Y.-Y. (-)-Epigallocatechin-3-Gallate (EGCG) Attenuates ArsenicInduced Cardiotoxicity in Rats. Food Chem. Toxicol. 2016, 93, 102-110. [CrossRef]

106. Chen, J.; Du, L.; Li, J.; Song, H. Epigallocatechin-3-Gallate Attenuates Cadmium-Induced Chronic Renal Injury and Fibrosis. Food Chem. Toxicol. 2016, 96, 70-78. [CrossRef]

107. Yin, S.-T.; Tang, M.-L.; Su, L.; Chen, L.; Hu, P.; Wang, H.-L.; Wang, M.; Ruan, D.-Y. Effects of Epigallocatechin-3-Gallate on Lead-Induced Oxidative Damage. Toxicology 2008, 249, 45-54. [CrossRef]

108. Hassan, E.; Kahilo, K.; Kamal, T.; Hassan, M.; Elgawish, M.S. The Protective Effect of Epigallocatechin-3-Gallate on Testicular Oxidative Stress in Lead-Induced Toxicity Mediated by Cyp19 Gene/Estradiol Level. Toxicology 2019, 422, 76-83. [CrossRef]

109. Nakazato, T.; Ito, K.; Ikeda, Y.; Kizaki, M. Green Tea Component, Catechin, Induces Apoptosis of Human Malignant B Cells via Production of Reactive Oxygen Species. Clin. Cancer Res. 2005, 11, 6040-6049. [CrossRef]

110. Kim, J.-Y.; Choi, J.-Y.; Lee, H.-J.; Byun, C.J.; Park, J.-H.; Park, J.H.; Cho, H.-S.; Cho, S.-J.; Jo, S.A.; Jo, I. The Green Tea Component (-)-Epigallocatechin-3-Gallate Sensitizes Primary Endothelial Cells to Arsenite-Induced Apoptosis by Decreasing c-Jun N-Terminal Kinase-Mediated Catalase Activity. PLoS ONE 2015, 10, e0138590. [CrossRef] 
111. Sarkar, N.; Sinha, D. Epigallocatechin-3-Gallate Partially Restored Redox Homeostasis in Arsenite-Stressed Keratinocytes. J. Appl. Toxicol. 2018, 38, 1071-1080. [CrossRef]

112. Yu, H.-N.; Shen, S.-R.; Yin, J.-J. Effects of Interactions of EGCG and Cd(2+) on the Growth of PC-3 Cells and Their Mechanisms. Food Chem. Toxicol. 2007, 45, 244-249. [CrossRef]

113. Abib, R.T.; Peres, K.C.; Barbosa, A.M.; Peres, T.V.; Bernardes, A.; Zimmermann, L.M.; Quincozes-Santos, A.; Fiedler, H.D.; Leal, R.B.; Farina, M.; et al. Epigallocatechin-3-Gallate Protects Rat Brain Mitochondria against Cadmium-Induced Damage. Food Chem. Toxicol. 2011, 49, 2618-2623. [CrossRef]

114. An, Z.; Qi, Y.; Huang, D.; Gu, X.; Tian, Y.; Li, P.; Li, H.; Zhang, Y. EGCG Inhibits Cd(2+)-Induced Apoptosis through Scavenging ROS Rather than Chelating Cd(2+) in HL-7702 Cells. Toxicol. Mech. Methods 2014, 24, 259-267. [CrossRef]

115. Bondad, S.E.C.; Kurasaki, M. Analysis of Cadmium, Epigallocatechin Gallate, and Vitamin C Co-Exposure on PC12 Cellular Mechanisms. Biol. Trace Elem. Res. 2020, 198, 627-635. [CrossRef]

116. Wu, F.; Sun, H.; Kluz, T.; Clancy, H.A.; Kiok, K.; Costa, M. Epigallocatechin-3-Gallate (EGCG) Protects against Chromate-Induced Toxicity in Vitro. Toxicol. Appl. Pharmacol. 2012, 258, 166-175. [CrossRef]

117. Chen, M.; Wang, F.; Cao, J.-J.; Han, X.; Lu, W.-W.; Ji, X.; Chen, W.-H.; Lu, W.-Q.; Liu, A.-L. (-)-Epigallocatechin-3-Gallate Attenuates the Toxicity of Methylmercury in Caenorhabditis Elegans by Activating SKN-1. Chem. Biol. Interact. 2019, 307, 125-135. [CrossRef]

118. Gu, Y.; Wang, Y.; Zhou, Q.; Bowman, L.; Mao, G.; Zou, B.; Xu, J.; Liu, Y.; Liu, K.; Zhao, J.; et al. Inhibition of Nickel NanoparticlesInduced Toxicity by Epigallocatechin-3-Gallate in JB6 Cells May Be through Down-Regulation of the MAPK Signaling Pathways. PLoS ONE 2016, 11, e0150954. [CrossRef]

119. Chen, L.; Yang, X.; Jiao, H.; Zhao, B. Tea Catechins Protect against Lead-Induced Cytotoxicity, Lipid Peroxidation, and Membrane Fluidity in HepG2 Cells. Toxicol. Sci. 2002, 69, 149-156. [CrossRef]

120. Ayyalasomayajula, N.; Ajumeera, R.; Chellu, C.S.; Challa, S. Mitigative Effects of Epigallocatechin Gallate in Terms of Diminishing Apoptosis and Oxidative Stress Generated by the Combination of Lead and Amyloid Peptides in Human Neuronal Cells. J. Biochem. Mol. Toxicol. 2019, 33, e22393. [CrossRef]

121. Weinreb, O.; Amit, T.; Mandel, S.; Youdim, M.B.H. Neuroprotective Molecular Mechanisms of (-)-Epigallocatechin-3-Gallate: A Reflective Outcome of Its Antioxidant, Iron Chelating and Neuritogenic Properties. Genes Nutr. 2009, 4, 283-296. [CrossRef]

122. Papuc, C.; Goran, G.V.; Predescu, C.N.; Nicorescu, V.; Stefan, G. Plant Polyphenols as Antioxidant and Antibacterial Agents for Shelf-Life Extension of Meat and Meat Products: Classification, Structures, Sources, and Action Mechanisms. Compr. Rev. Food Sci. Food Saf. 2017, 16, 1243-1268. [CrossRef]

123. Pannala, A.S.; Rice-Evans, C.A.; Halliwell, B.; Singh, S. Inhibition of Peroxynitrite-Mediated Tyrosine Nitration by Catechin Polyphenols. Biochem. Biophys. Res. Commun. 1997, 232, 164-168. [CrossRef]

124. Valcic, S.; Burr, J.A.; Timmermann, B.N.; Liebler, D.C. Antioxidant Chemistry of Green Tea Catechins. New Oxidation Products of (-)-Epigallocatechin Gallate and (-)-Epigallocatechin from Their Reactions with Peroxyl Radicals. Chem. Res. Toxicol. 2000, 13, 801-810. [CrossRef] [PubMed]

125. Guo, Q.; Zhao, B.; Li, M.; Shen, S.; Xin, W. Studies on Protective Mechanisms of Four Components of Green Tea Polyphenols against Lipid Peroxidation in Synaptosomes. Biochim. Biophys. Acta 1996, 1304, 210-222. [CrossRef]

126. Teng, Y.; Zhao, J.; Ding, L.; Ding, Y.; Zhou, P. Complex of EGCG with Cu(II) Suppresses Amyloid Aggregation and Cu(II)-Induced Cytotoxicity of $\alpha$-Synuclein. Molecules 2019, 24, 2940. [CrossRef] [PubMed]

127. Wang, D.; Kim, D.; Shin, C.-H.; Zhao, Y.; Park, J.-S.; Ryu, M. Evaluation of Epigallocatechin Gallate (EGCG) to Remove Pb(II) Using Spectroscopic and Quantum Chemical Calculation Method. Environ. Earth Sci. 2019, 78, 138. [CrossRef]

128. Wang, Y.; Tang, Y.; Li, Z.; Hua, Q.; Wang, L.; Song, X.; Zou, B.; Ding, M.; Zhao, J.; Tang, C. JoInt Toxicity of a Multi-Heavy Metal Mixture and Chemoprevention in Sprague Dawley Rats. Int. J. Environ. Res. Public Health 2020, 17, 1451. [CrossRef]

129. Pall, M.L.; Levine, S. Nrf2, a Master Regulator of Detoxification and Also Antioxidant, Anti-Inflammatory and Other Cytoprotective Mechanisms, Is Raised by Health Promoting Factors. Sheng Li Xue Bao 2015, 67, 1-18.

130. Toyama, T.; Sumi, D.; Shinkai, Y.; Yasutake, A.; Taguchi, K.; Tong, K.I.; Yamamoto, M.; Kumagai, Y. Cytoprotective Role of Nrf2/Keap1 System in Methylmercury Toxicity. Biochem. Biophys. Res. Commun. 2007, 363, 645-650. [CrossRef]

131. Toyama, T.; Shinkai, Y.; Yasutake, A.; Uchida, K.; Yamamoto, M.; Kumagai, Y. Isothiocyanates Reduce Mercury Accumulation via an Nrf2-Dependent Mechanism during Exposure of Mice to Methylmercury. Environ. Health Perspect. 2011, 119, 1117-1122. [CrossRef]

132. Stefanson, A.L.; Bakovic, M. Dietary Regulation of Keap1/Nrf2/ARE Pathway: Focus on Plant-Derived Compounds and Trace Minerals. Nutrients 2014, 6, 3777-3801. [CrossRef]

133. Gogoi, K.; Manna, P.; Dey, T.; Kalita, J.; Unni, B.G.; Ozah, D.; Baruah, P.K. Circulatory Heavy Metals (Cadmium, Lead, Mercury, and Chromium) Inversely Correlate with Plasma GST Activity and GSH Level in COPD Patients and Impair NOX4/Nrf2/GCLC/GST Signaling Pathway in Cultured Monocytes. Toxicol. Vitr. 2019, 54, 269-279. [CrossRef]

134. Matzinger, M.; Fischhuber, K.; Heiss, E.H. Activation of Nrf2 Signaling by Natural Products-Can It Alleviate Diabetes? Biotechnol. Adv. 2018, 36, 1738-1767. [CrossRef]

135. Na, H.-K.; Kim, E.-H.; Jung, J.-H.; Lee, H.-H.; Hyun, J.-W.; Surh, Y.-J. (-)-Epigallocatechin Gallate Induces Nrf2-Mediated Antioxidant Enzyme Expression via Activation of PI3K and ERK in Human Mammary Epithelial Cells. Arch. Biochem. Biophys. 2008, 476, 171-177. [CrossRef] [PubMed] 
136. Zwolak, I. Vanadium Carcinogenic, Immunotoxic and Neurotoxic Effects: A Review of in Vitro Studies. Toxicol. Mech. Methods 2014, 24, 1-12. [CrossRef]

137. Liu, T.; Zhang, L.; Joo, D.; Sun, S.-C. NF-KB Signaling in Inflammation. Signal Transduct. Target. Ther. 2017, 2, 17023. [CrossRef]

138. Ye, N.; Ding, Y.; Wild, C.; Shen, Q.; Zhou, J. Small Molecule Inhibitors Targeting Activator Protein 1 (AP-1). J. Med. Chem. 2014, 57, 6930-6948. [CrossRef] [PubMed]

139. De Oliveira, M.R.; Nabavi, S.F.; Daglia, M.; Rastrelli, L.; Nabavi, S.M. Epigallocatechin Gallate and Mitochondria-A Story of Life and Death. Pharmacol. Res. 2016, 104, 70-85. [CrossRef]

140. Schroeder, E.K.; Kelsey, N.A.; Doyle, J.; Breed, E.; Bouchard, R.J.; Loucks, F.A.; Harbison, R.A.; Linseman, D.A. Green Tea Epigallocatechin 3-Gallate Accumulates in Mitochondria and Displays a Selective Antiapoptotic Effect against Inducers of Mitochondrial Oxidative Stress in Neurons. Antioxid. Redox Signal. 2009, 11, 469-480. [CrossRef]

141. Pan, H.; Chen, J.; Shen, K.; Wang, X.; Wang, P.; Fu, G.; Meng, H.; Wang, Y.; Jin, B. Mitochondrial Modulation by Epigallocatechin 3-Gallate Ameliorates Cisplatin Induced Renal Injury through Decreasing Oxidative/Nitrative Stress, Inflammation and NF-KB in Mice. PLoS ONE 2015, 10, e0124775. [CrossRef]

142. Sang, S.; Yang, I.; Buckley, B.; Ho, C.-T.; Yang, C.S. Autoxidative Quinone Formation in Vitro and Metabolite Formation in Vivo from Tea Polyphenol (-)-Epigallocatechin-3-Gallate: Studied by Real-Time Mass Spectrometry Combined with Tandem Mass Ion Mapping. Free. Radic. Biol. Med. 2007, 43, 362-371. [CrossRef]

143. Sergi, C.M. Epigallocatechin-3-Gallate Toxicity in Children: A Potential and Current Toxicological Event in the Differential Diagnosis with Virus-Triggered Fulminant Hepatic Failure. Front. Pharmacol. 2020, 10. [CrossRef]

144. Kajiya, K.; Kumazawa, S.; Nakayama, T. Steric Effects on Interaction of Tea Catechins with Lipid Bilayers. BioSci. Biotechnol. Biochem. 2001, 65, 2638-2643. [CrossRef]

145. Kucera, O.; Mezera, V.; Moravcova, A.; Endlicher, R.; Lotkova, H.; Drahota, Z.; Cervinkova, Z. In Vitro Toxicity of Epigallocatechin Gallate in Rat Liver Mitochondria and Hepatocytes. Oxidative Med. Cell. Longev. 2015, 2015, 476180. [CrossRef]

146. Elbling, L.; Weiss, R.-M.; Teufelhofer, O.; Uhl, M.; Knasmueller, S.; Schulte-Hermann, R.; Berger, W.; Micksche, M. Green Tea Extract and (-)-Epigallocatechin-3-Gallate, the Major Tea Catechin, Exert Oxidant but Lack Antioxidant Activities. Faseb J. 2005, 19, 807-809. [CrossRef]

147. Grzesik, M.; Bartosz, G.; Stefaniuk, I.; Pichla, M.; Namieśnik, J.; Sadowska-Bartosz, I. Dietary Antioxidants as a Source of Hydrogen Peroxide. Food Chem. 2019, 278, 692-699. [CrossRef]

148. Long, L.; Halliwell, B. Artefacts in Cell Culture: Pyruvate as a Scavenger of Hydrogen Peroxide Generated by Ascorbate or Epigallocatechin Gallate in Cell Culture Media. Biochem. Biophys. Res. Commun. 2009, 388, 700-704. [CrossRef]

149. Scholl, C.; Lepper, A.; Lehr, T.; Hanke, N.; Schneider, K.L.; Brockmöller, J.; Seufferlein, T.; Stingl, J.C. Population Nutrikinetics of Green Tea Extract. PLoS ONE 2018, 13, e0193074. [CrossRef]

150. Haratifar, S.; Meckling, K.; Corredig, M. Bioefficacy of Tea Catechins Encapsulated in Casein Micelles Tested on a Normal Mouse Cell Line (4D/WT) and Its Cancerous Counterpart (D/v-Src) before and after in Vitro Digestion. Food Funct. 2014, 5, 1160-1166. [CrossRef] [PubMed]

151. Dube, A.; Nicolazzo, J.A.; Larson, I. Chitosan Nanoparticles Enhance the Plasma Exposure of (-)-Epigallocatechin Gallate in Mice through an Enhancement in Intestinal Stability. Eur. J. Pharm. Sci. 2011, 44, 422-426. [CrossRef]

152. Peters, C.M.; Green, R.J.; Janle, E.M.; Ferruzzi, M.G. Formulation with Ascorbic Acid and Sucrose Modulates Catechin Bioavailability from Green Tea. Food Res. Int. 2010, 43, 95-102. [CrossRef]

153. Mazzanti, G.; Menniti-Ippolito, F.; Moro, P.A.; Cassetti, F.; Raschetti, R.; Santuccio, C.; Mastrangelo, S. Hepatotoxicity from Green Tea: A Review of the Literature and Two Unpublished Cases. Eur. J. Clin. Pharm. 2009, 65, 331-341. [CrossRef]

154. Wang, D.; Taylor, E.W.; Wang, Y.; Wan, X.; Zhang, J. Encapsulated Nanoepigallocatechin-3-Gallate and Elemental Selenium Nanoparticles as Paradigms for Nanochemoprevention. Int. J. Nanomed. 2012, 7, 1711-1721. [CrossRef]

155. National Toxicology Program (NTP). NTP Technical Report on the Toxicology Studies of Green Tea Extract in F344/NTac Rats and B6C3F1/N Mice and Toxicology and Carcinogenesis Studies of Green Tea Extract in Wistar Han [Crl:Wi(Han)] Rats and B6C3F1/N Mice (Gavage Studies); NCBI: Bethesda, MD, USA, 2016; p. 585. [CrossRef]

156. Emoto, Y.; Yoshizawa, K.; Kinoshita, Y.; Yuki, M.; Yuri, T.; Yoshikawa, Y.; Sayama, K.; Tsubura, A. Green Tea Extract-Induced Acute Hepatotoxicity in Rats. J. Toxicol. Pathol. 2014, 27, 163-174. [CrossRef] [PubMed]

157. Pae, M.; Ren, Z.; Meydani, M.; Shang, F.; Smith, D.; Meydani, S.N.; Wu, D. Dietary Supplementation with High Dose of Epigallocatechin-3-Gallate Promotes Inflammatory Response in Mice. J. Nutr. Biochem. 2012, 23, 526-531. [CrossRef] [PubMed]

158. Rasheed, N.O.A.; Ahmed, L.A.; Abdallah, D.M.; El-Sayeh, B.M. Nephro-Toxic Effects of Intraperitoneally Injected EGCG in Diabetic Mice: Involvement of Oxidative Stress, Inflammation and Apoptosis. Sci. Rep. 2017, 7, 40617. [CrossRef] [PubMed]

159. Wang, D.; Wei, Y.; Wang, T.; Wan, X.; Yang, C.S.; Reiter, R.J.; Zhang, J. Melatonin Attenuates (-)-Epigallocatehin-3-Gallate-Triggered Hepatotoxicity without Compromising Its Downregulation of Hepatic Gluconeogenic and Lipogenic Genes in Mice. J. Pineal Res. 2015, 59, 497-507. [CrossRef] [PubMed]

160. Church, R.J.; Gatti, D.M.; Urban, T.J.; Long, N.; Yang, X.; Shi, Q.; Eaddy, J.S.; Mosedale, M.; Ballard, S.; Churchill, G.A.; et al. Sensitivity to Hepatotoxicity Due to Epigallocatechin Gallate Is Affected by Genetic Background in Diversity Outbred Mice. Food Chem. Toxicol. 2015, 76, 19-26. [CrossRef] [PubMed]

161. Lambert, J.D.; Kennett, M.J.; Sang, S.; Reuhl, K.R.; Ju, J.; Yang, C.S. Hepatotoxicity of High Oral Dose (-)-Epigallocatechin-3-Gallate in Mice. Food Chem. Toxicol. 2010, 48, 409-416. [CrossRef] 